\title{
10. OLIGOCENE TO RECENT PLANKTONIC FORAMINIFERA AND STRATIGRAPHY OF THE LEG 15 SITES IN THE CARIBBEAN SEA
}

\author{
Hans M. Bolli, Geology Department, Swiss Federal Institute of Technology, Zurich, Switzerland \\ and \\ Isabella Premoli Silva, Geological Institute, University of Milano, Italy
}

Introduction

Taxonomy of Leg 15 Oligocene to Recent planktonic foraminifera Taxonomic changes from Leg 4 Initial Report Supplementary taxonomic remarks (supplements those in Leg 4 Initial Report, Bolli 1970)

Stratigraphic ranges of some index fossils

Zonation based on planktonic foraminifera Pliocene zones

Pleistocene-Holocene zones

Pleistocene-Holocene correlations

\section{CONTENTS}

475

475

476

477

478

479

482

483

\section{INTRODUCTION}

All nine sites of Leg 15 are in the Caribbean Sea, where three sites were drilled previously during Leg 4 (Figure 1). While none of the Leg 4 sites reached Cretaceous or acoustic basement, this goal was reached in five sites of Leg 15 by improved drilling methods and successful reentry. In the four other sites, Cretaceous or acoustic basement was either not the objective or was out of reach because of excessive sediment thickness.

The shipboard work on foraminifera of Sites 146 through 154 was carried out jointly by both authors irrespective of the age of penetrated strata. For the preparation of initial reports, however, it was found to be advantageous to divide the stratigraphic section into two parts. The part on Cretaceous to Late Eocene was written largely by Premoli Silva and that on Oligocene to Recent by Bolli.

Compared with the Caribbean Leg 4 sites, no essential differences were recorded in the Oligocene to Recent faunas. The taxonomic treatment of the planktonic foraminifera is therefore much the same as in Leg 4 (Bolli, 1970). However, the zonation of the Pliocene to Recent can now be refined by recognizing a number of new subzones. With this finer subdivision in the Late Pleistocene/Holocene it is now believed possible to detect missing parts of this interval, which are often lost by disturbances in the drilling process.

Such a refined zonation of the late Quaternary became possible largely through the much expanded Late Pleistocene-Holocene sequence in Site 147, drilled in the Cariaco Basin (Trench) and the Vema 26-119 piston core taken in the central Venezuela Basin in the neighborhood of Sites 29 and 149.

Distribution of the Oligocene to Recent foraminifera 483 Site 146

Site 149

Site 147

Site 148

Site 150

Site 151

Site 153

Site 154

Acknowledgments

References

A comparison of the Oligocene to Recent in the continuously cored Site 29 of Leg 4 and Site 149 of Leg 15 shows some improvement in the recovery of the penetrated zones. But the opinion expressed in the Leg 4 Initial Report (Bolli 1970), that the central Venezuela Basin is not the ideal place for obtaining a continuous and well-preserved section, has been confirmed again by the Site 149 results. Though most Oligocene to Recent planktonic foraminiferal zones have been recognized in the two sites combined, the faunal preservation is often strongly affected by $\mathrm{CaCO}_{3}$ dissolution.

Site 147, drilled in the Cariaco Trench off the Venezuelan north coast, is an outstanding section as far as the Pleistocene-Holocene is concerned. Before drilling had to be suspended because of high gas pressure, 162 meters of mostly euxinic sediments were continuously cored. They represent the Holocene and Late Pleistocene to about 300,000 years ago. The rich and well-preserved planktonic foraminiferal fauna was found well suited for biostratigraphic, as well as climatological and variability investigations, which are dealt with in a separate chapter of this volume (Rögl and Bolli).

\section{TAXONOMY OF LEG 15 OLIGOCENE TO RECENT PLANKTONIC FORAMINIFERA}

The Oligocene to Recent planktonic foraminifera of Leg 15 are treated taxonomically in much the same way as in Leg 4. Reference is therefore made to Leg 4 Initial Report, p. 578-584, where comments are made on the species and subspecies. Many of the taxa, including all stratigraphically important Pliocene and Pleistocene forms, are illustrated in that report on plates 1 through 7, p. 226-641. 


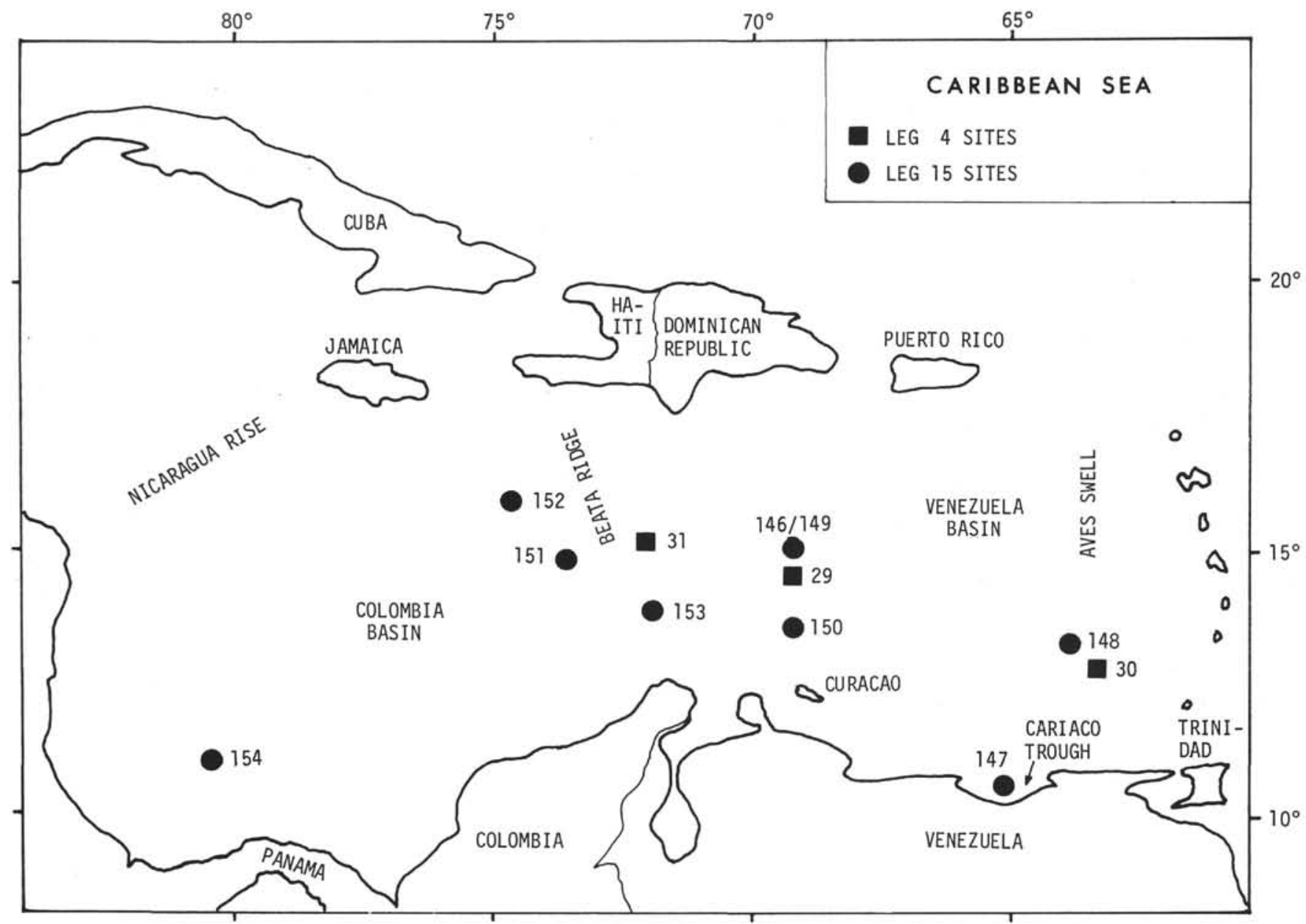

Figure 1. Location of Leg 4 and 15 sites in the Caribbean Sea.

Several forms were briefly characterized and figured but not formally named. One of them, Globorotalia crassaformis $B$ is here described as Globorotalia hessi Bolli and Premoli Silva, n. sp. Another, Globorotalia exilis A, is recognized as Globorotalia pertenuis Beard. The subdivision by Cita in the Leg 13 Initial Report (Cita, 1973) of Globorotalia margaritae into three subspecies, $G$. margaritae primitiva, G. margaritae margaritae and $G$. margaritae evoluta is adopted here.

\section{Taxonomic Changes from Leg 4 Initial Report}

Globorotalia crassaformis B Globorotalia hessi Bolli and

\section{Globorotalia exilis $A$}

\section{Globorotalia margaritae}

Bolli and Bermudez

\section{Globigerina subcretacea Lomnicki} Premoli, n. sp.

Globorotalia pertenuis Beard

Globorotalia margaritae evoluta Cita

Globorotalia margaritae margaritae Bolli and Bermudez

Globorotalia margaritae primitiva Cita

Globorotaloides hexagonus (Natland)
Supplementary Taxonomic Remarks (Supplements those in Leg 4 Initial Report, Bolli 1970)

Globorotalia hessi Bolli and Premoli Silva, n.sp.

Globorotalia crassaformis B. Bolli, 1970, p. 580-581, pl. 4, figs. 13-16. Globorotalia crassaformis (Galloway and Wissler), Lamb and Beard, 1972, pl. 21, figs. 1-8.

Shape of test very low trochospiral, flat on spiral side except for raised edges of last few chambers. Last chamber often slightly offset obliquely downwards. Umbilical side strongly convex, somewhat inflated between periphery and umbilical margin. Equatorial periphery roughly quadrangular in outline only very slightly lobate. In side view, rounded to subacute, particularly on the last chamber which is often somewhat smaller and thinner walled compared with earlier ones; there may be a faint peripheral keel. Wall calcareous, perforate, thick, of ten covered with pustules, particularly in central portion of spiral side and towards umbilical margin. Chambers rounded to subangular in side view compressed laterally, four in last whorl, increasing slowly in size. Sutures between last chambers on spiral side fairly straight and almost tangential to inner spiral portion, slightly depressed between last chambers; on umbilical side radial, depressed between last chambers. Umbilicus very narrow, deep. Aperture a narrow slit, interio-marginal, extraumbilicalumbilical, sometimes with a weak lip. Coiling predominantly sinistral in the Caribbean area. Largest diameter of holotype: $0.5 \mathrm{~mm}$. 
Stratigraphic range: Pleistocene. Base Globorotalia hessi Subzone (subzone of Globorotalia truncatulinoides truncatulinoides Zone) to within Globigerina calida calida Subzone.

Locality: Holotype (C-27611) and figures paratypes (C-27612-27614) from Leg 4, Site 19, Core 1, Section $3(10-12 \mathrm{~cm})$ - central Venezuela Basin, Caribbean Sea $\left(14^{\circ} 47.11^{\prime} \mathrm{N} ; 69^{\circ}\right.$ 19.36 'W); Globorotalia truncatulinoides truncatulinoides Zone, Pleistocene.

Remarks: A comparison of the holotypes of Globorotalia crassaformis and $G$. hessi shows that the new species is larger in size $(0.5$ against $0.4 \mathrm{~mm})$, is more distinctly quadrangular, and is less lobate in equatorial view. While the spiral side of $G$. crassaformis is described as flat, in $G$. hessi it is often concave. The chambers of the new species increase in size less rapidly, and the final chamber never reaches such a large relative size as in the $G$. crassaformis holotype. In peripheral view, the chambers of $G$. hessi are more inflated. Further, its walls are more robust and are usually covered, at least partially, by pustules. In contrast to $G$. hessi, sutures on the spiral side of $G$. crassaformis are distinctly curved, and those on the umbilical side are more incised. $G$. hessi has a different stratigraphic range; in the Caribbean area it is restricted to part of the Pleistocene whereas Globorotalia crassaformis extends from Early Pliocene to Recent.

The species is named for Harry H. Hess in remembrance of his outstanding contributions to geology.

\section{Globorotalia inflata A}

The species determined in Leg 4 Initial Report and also here as Globorotalia inflata $A$ has a distinct range from within the Globorotalia margaritae Zone to within the Globorotalia exilis Subzone. The small, delicate form was regarded in the Leg 4 report as the possible ancestor of Globorotalia inflata. However, in the Caribbean area there is generally a gap between the last occurrence of $G$. inflata $A$ and the first appearance of $G$. inflata, and no clearly intermediate forms could be established. A connection between the two forms therefore, remains to be established. Furthermore, the possibility of $G$. inflata $A$ being a synonym of $G$. bononiensis described from Italy remains to be checked.

\section{Globorotalia margaritae Bolli and Bermudez}

It was already pointed out in the Leg 4 Report, p. 581, that "In the upper part of the Globorotalia margaritae Zone of Sites 29 and 31 , specimens have a tendency to grow larger by adding one or two more chambers..." This was also illustrated on Plate 8, figs. 4-7, p. 641 .

Cita, in the Leg 13 Initial Report, p. 1349, has now demonstrated an evolutionary trend from small, keelless forms to large, lobate and carinate ones and has established the three subspecies $G$. margaritae primitiva, G. margaritae margaritae and G. margaritae evoluta, which appear in stratigraphic succession. Cita has used this trend for dividing the original Globorotalia margaritae Zone into a Globorotalia margaritae margaritae Zone and a Globorotalia mar. garitae evoluta Zone.

The interval containing the early part of the Globorotalia margaritae evolution, $G$. margaritae primitiva to $G$. margaritae margaritae, is strongly affected by $\mathrm{CaCO}_{3}$ dissolution in the Caribbean sites. Probably for this reason $G$. margaritae primitiva has not as yet been observed there. The trend from $G$. margaritae margaritae to $G$. margaritae evoluta is, however, well represented in the Leg 4 sites and again in some of the Leg 15 sites.

$G$. margaritae has a wide paleogeographic distribution from tropical in to temperate areas with apparently the same evolutionary features in the Caribbean, Gulf of Mexico, tropical-subtropical Atlantic, Mediterranean and Java. Its subdivision into three subspecies as proposed by Cita thus offers a finer biostratigraphic breakdown of the Early Pliocene on a worldwide scale.

\section{Globorotalia pertenuis Beard-Globorotalia exilis Blow}

The specimens described in the Leg 4 Initial Report as Globorotalia exilis $A$ are here assigned to Globorotalia pertenuis Beard. They differ from $G$. exilis in the higher number of chambers in the last whorl, 7 to 9 against 5 to 6 , and an often stronger development of the peripheral keel, particularly in the early chambers of the last whorl. From distributions observed in several
Leg 4,14 , and 15 sites, it is apparent that $G$. pertenuis is the ancestral form of $G$. exilis, with intermediate forms present in the basal part of the Globorotalia miocenica. Zone, where G. pertenuis gradually becomes replaced by $G$. exilis.

$G$. pertenuis has a stratigraphic range closely comparable with that of $G$. multicamerata, from which it differs morphologically in having a less robust test and a much weaker peripheral keel in the early portion (Bolli, 1970, Pl. 7, figs. 14, 18). However, intermediate forms exist which may be difficult to place in one or the other species.

Lamb and Beard, 1972 , p. 55 , ascribe to G. exilis Blow, 1967, "a certain affinity with $G$. pertenuis, but with fewer and less lobate chambers." They regard $G$. exilis as intermediate between their $G$. praemiocenica and $G$. pertenuis and insufficiently distinct morphologically to have important stratigraphic usage. From Legs 4 and 15 evidence, however, G. exilis has evolved from $G$. pertenuis and has a distinct morphology and stratigraphic range.

\section{STRATIGRAPHIC RANGES OF SOME INDEX FOSSILS}

Difficulties in the zonal application of planktonic foraminifera due to ecologic factors, interruption or condensation in sedimentation, etc., were discussed to some extent in the Leg 4 Initial Report, p. 584-586. Mention was particularly made of the Globorotalia tumida plesiotumida-G. tumida tumida, and the $G$. truncatulinoides tosaensis-G. trunctulinoides truncatulinoides evolutionary series, and the extinction level of Globoquadrina altispira; all used for biostratigraphic purposes. The irregular occurrences in the Pliocene-Pleistocene of various planktonic index species makes it imperative to use them with care for biostratigraphic purposes.

An example of this in the Caribbean area is the interrupted evolutionary sequence of Pulleniatina beginning with $P$. obliquiloculata primalis within the Globorotalia margaritae margaritae Subzone. This form disappears around the Globorotalia margaritae margaritae/Globorotalia margaritae evoluta Subzone boundary. It reappears as Pulleniatina obliquiloculata obliquiloculata only within the Globorotalia miocenica Zone, or even as late as the Globorotalia truncatulinoides cf tosaensis Zone.

Globorotalia tumida tumida is widespread, though not continuously present in the Globorotalia truncatulinoides truncatulinoides Zone, but almost unknown below. $G$. tumida plesiotumida, its ancestral form, makes a brief appearance in the Globorotalia margaritae Zone of well Cubagua 1 (Bolli and Bermudez, 1965). In contrast, an uninterrupted $G$. tumida plesiotumida-G. tumida tumida evolutionary sequence can be followed in Bodjonegoro well 1 of Java (Bolli, 1966b).

Globorotalia truncatulinoides tosaensis is generally considered to be the ancestor of $G$. truncatulinoides truncatulinoides. However, sections where a gradual evolution from tosaensis into truncatulinoides can be followed are, to the writers' knowledge, virtually unknown.

The usual picture is the sudden appearance of already fully developed $G$. truncatulinoides truncatulinoides. Scarce G. truncatulinoides tosaensis forms are often present in the Caribbean sections immediately before and for some time after first occurrences of $G$. truncatulinoides truncatulinoides, but one never has the impression of an evolutionary passage from one subspecies into the other. Sporadic $G$. truncatulinoides tosaensis may appear much earlier, at least for short intervals. Examples are the Caribbean Sites, 29, 30 , and 148 , where the form makes a brief appearance 
around the Globorotalia margaritae/Globorotalia miocenica Zone boundary.

Parts, at least, of an assumed Globorotalia truncatulinoides tosaensis- $G$. truncatulinoides truncatulinoides evolutionary sequence are cut out in certain areas of the Caribbean, Gulf of Mexico, tropical-subtropical Atlantic, and the Mediterranean. Sections with a sudden appearance of already fully evolved $G$. truncatulinoides truncatulinoides, without clear link to ancestral G. truncatulinoides tosaensis, do not, therefore, necessarily contain the earliest G. truncatulinoides truncatulinoides. Where the assumed evolution from tosaensis could take place uninterruptedly, the base of $G$. truncatulinoides would likely be lower than in the areas mentioned above. This apparent instability of the Globorotalia truncatulinoides truncatulinoides datum should be taken into consideration in the determination of the Pliocene/Pleistocene boundary.

A gap between the extinction level of Globorotalia miocenica or $G$. exilis and the first occurrence of $G$. truncatulinoides truncatulinoides exists in the continuously cored Caribbean Sites 30, 31, 148, 154 (154A) of Legs 4 and 15, and also in Atlantic Site 141 of Leg 14 (Beckmann, 1971). Lamb and Beard (1972) obtained a rather different picture from their Gulf of Mexico cores. In a Sigsbee Knolls piston core and cores from continental slope holes A and B they show an overlap of Globorotalia miocenica and $G$. pertenuis (in which Beard apparently included $G$. exilis) with Globorotalia truncatulinoides truncatulinoides. But in slope holes C and D which are geographically close to hole $B$ there is a gap between these taxa. Like the present author in his Leg 4 Report, Beard and Lamb have not found an overlap in Jamaica. This they attribute to a hiatus in that area.

As already pointed out in the Leg 4 Initial Report, such inconsistencies of observed ranges in different localities may be largely responsible for the often contradictory Pliocene-Pleistocene-Holocene zonal schemes now in existence.

The restricted ranges of the following taxa are of significance for the subdivision of the Caribbean PleistoceneHolocene.

1) Globorotalia crassaformis viola, ranging up from the Globorotalia miocenica Zone, becomes extinct within the Early Pleistocene Subzone of this name, and appears shortly before Globorotalia hessi.

2) Globorotalia hessi, n.sp. has a range from within the lower part of the Pleistocene (determining there the base of the Globorotalia hessi Subzone) to within the Globigerina calida calida Subzone.

3) Globorotaloides hexagonus, described in the Leg 4 Initial Report as Globigerina subcretacea, becomes extinct within the Globigerina calida calida Subzone, probably very slightly prior to Globorotalia hessi. This extinction level apparently holds good for the tropical-subtropical Atlantic province. In the Pacific and Indian oceans the species apparently continues to Recent.

4) The extinction of Globorotalia tumida flexuosa, approximately 80,000 years ago, provides a good datum within the Caribbean Pleistocene, where it determines the top of the newly erected Globigerina calida calida Subzone.

5) Globigerina calida calida makes its first appearance in Site 147 sediment deposited approximately 150,000 years ago. This is taken as the base of Globigerina calida calida Subzone, which reaches to the extinction level of Globorotalia tumida flexuosa, approximately 80,000 years ago. The subspecies continues to Recent.

6) Globorotalia fimbriata is known only from the Holocene in the Caribbean where it is now taken as the marker for the subzone of that name.

\section{ZONATION BASED ON PLANKTONIC FORAMINIFERA}

The zonal system applied in Leg 4 is largely that of Bolli, $1966 \mathrm{a}$, with some modifications in the Late Miocene and Pliocene, based on the DSDP Caribbean Sites 29 through 31 and observations on Jamaica land sections (Leg 4 Initial Report, p. 584-587, 593-597). The Globorotalia margaritae Zone was moved from Late Miocene into Early Pliocene. The zones immediately above, the Globoquadrina altispira altispira and the Globoquadrina altispira altispira/ Globorotalia truncatulinoides zones, were replaced by the Globorotalia exilis/miocenica and the Globorotalia truncatulinoides of tosaensis zones, representing the Middle and Late Pliocene respectively. The Globorotalia truncatulinoides Zone, shown to range from Late Pliocene to Recent in Bolli 1966a, was renamed the Globorotalia truncatulinoides truncatulinoides Zone and occupies the Pleistocene-Holocene interval in the Leg 4 Initial Report.

Leg 15 results confirmed what was already evident from Leg 4 Sites 29 through 31: that the Globorotalia margaritae and the Globorotalia exilis/miocenica zones could be further subdivided on the basis of a number of distinct first and last occurrences. This is now done in this report (Figure 2).

The justification of the Globorotalia truncatulinoides $\mathrm{cf}$ tosaensis Zone as a distinct interval between the Globorotalia exilis/miocenica and the Globorotalia truncatulinoides truncatulinoides zones was generally confirmed in Leg 15, and also in Atlantic Site 141 of Leg 14.

Because of its extraordinary Pleistocene thickness, Site 147 is particularly suitable for a subdivision of the Pleistocene by planktonic foraminifera. Though measuring some 162 meters, only its upper part to approximately 300,000 years was recovered. Several distinct faunal changes take place within this interval permitting its subdivision and also the separation of the Holocene from the Pleistocene. Based on datums of Sites $29,31,148,154$ (154A) and Vema piston core 26-119 in particular, it is also possible to subdivide the lower part of the Caribbean Pleistocene. Such divisions allow a closer correlation between sections and a better and more accurate detection of missing parts of the Pleistocene-Holocene section, which may have resulted from drilling disturbances in the DSDP cores (see Figure 3).

The new subzonation is applicable within the Caribbean. It probably can be extended into the Gulf of Mexico and the tropical-subtropical Atlantic.

The established Pliocene-Pleistocene zones as used in Leg 4 are here retained, and their new subdivisions are expressed as subzones. This offers the advantage that these zones, which are generally recognizable in the Caribbean-Gulf of Mexico area, in the tropical-subtropical Atlantic and partially in the Mediterranean, can still be applied where no further precision is required or possible. 


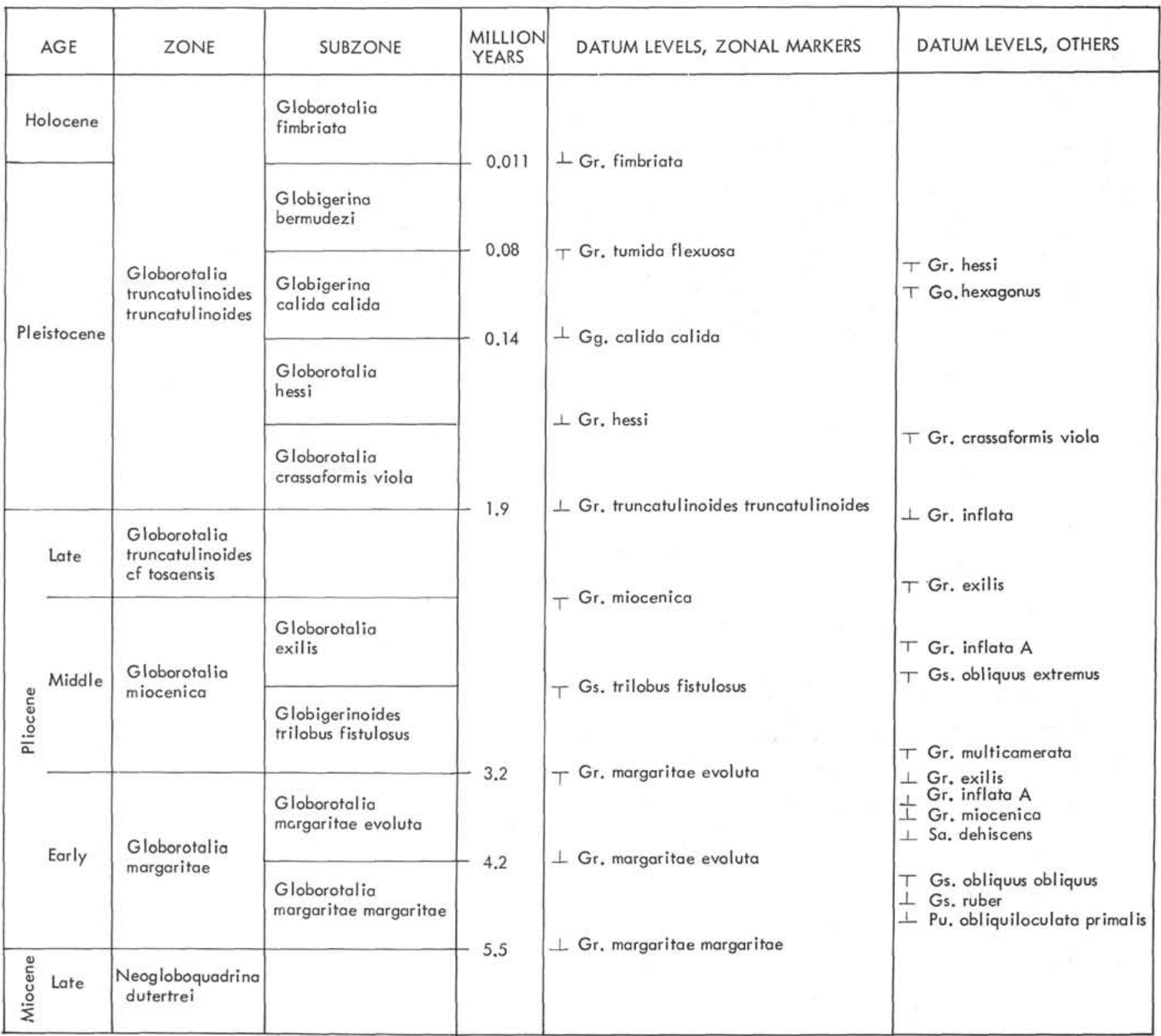

Figure 2. Caribbean Pliocene to Holocene zonation scheme and datum levels.

Pliocene Zones

\section{Globorotalia margaritae Zone}

Definition: Range of zonal marker.

Cita describes the evolutionary lineage of Globorotalia margaritae in the Mediterranean Leg 13 (Cita, 1973) and proposes a splitting of the species into three subspecies: an early $G$. margaritae primitiva, a $G$. margaritae margaritae as the central form, and a late G. margaritae evoluta. G. margaritae margaritae and $G$. margaritae evoluta are used for a subdivision of the original Globorotalia margaritae Zone. A Sphaeroidinellopsis Acme-zone preceding the Globorotalia margaritae margaritae Zone of Cita's Mediterranean zonal scheme may represent the basal part of the Globorotalia margaritae Zone as originally defined. Because of the often considerable thickness of the Globorotalia margaritae Zone, Cita's subdivision appears justified also in the Caribbean area, particularly since the branching off of $G$. margaritae evoluta from $G$. margaritae margaritae occurs approximately in the middle of the zone.

There is good evidence in the Caribbean from Legs 4 and 15 that the Globorotalia margaritae Zone could be subdivided still further based on events such as the extinction of Globigerinoides obliquus obliquus and Pulleniatina obliquiloculata primalis, or the first occurrence of Globorotalia inflata A, Globigerinoides ruber, Sphaeroidinella dehiscens and Globorotalia miocenica. All these events can serve as datum levels in addition to the present zonal system.

The two subzones of the Globorotalia margaritae Zone, Globorotalia margaritae margaritae and Globorotalia margaritae evoluta, are defined below. 


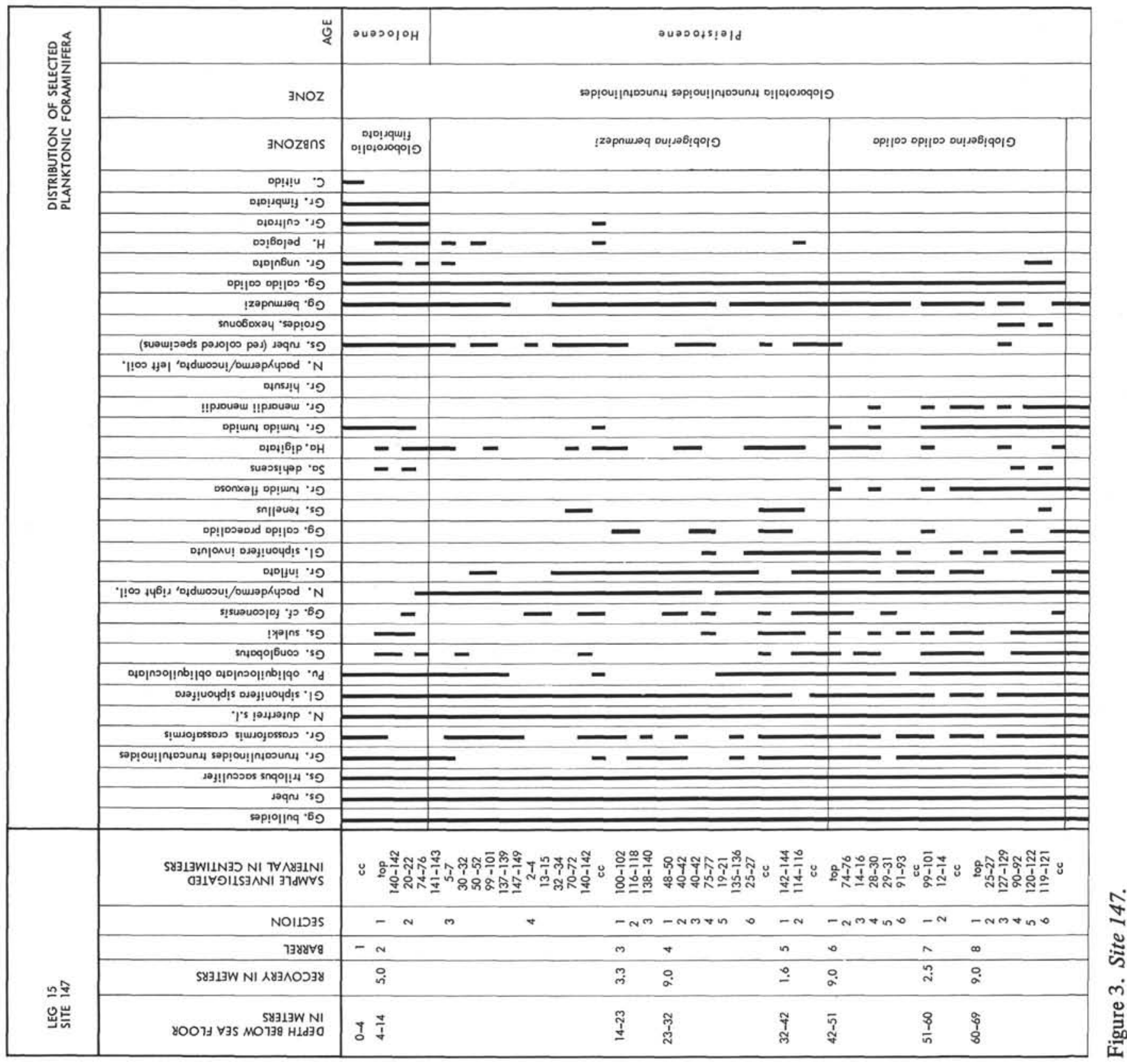

\section{Globorotalia margaritae margaritae Subzone}

Definition: Interval with zonal marker, from first occurrence of Globorotalia margaritae s.l. to the first occurrence of Globorotalia margaritae evoluta.

Remarks: Globigerinoides obliquus obliquus and-at least locally in the Caribbean area-dextrally coiling Pulleniatina obliquiloculata primalis become extinct close to the top of the subzone. In the Caribbean sections first occurrences of distinct forms within the subzone are: Pulleniatina obliquiloculata primalis (sinistrally coiling), Globorotalia multicamerata, Globorotalia crassaformis, Globorotalia pertenuis, Globigerinoides ruber. Sphaeroidinellopsis seminulina $A$ has its short range beginning slightly before or with Globorotalia margaritae evoluta and continues into the Globorotalia margaritae evoluta Zone.

\section{Globorotalia margaritae evoluta Subzone}

Definition: Range of zonal marker, from its development from Globorotalia margaritae margaritae to its extinction.

Remarks: Within this subzone, Globigerina venezuelana which occurs rather erratically in the Caribbean sections of the Globorotalia margaritae Zone, becomes extinct. Sphaeroidinella dehiscens and Globorotalia miocenica first appear in the subzone.

\section{Globorotalia exilis/miocenica Zone}

A number of characteristic species become extinct within the Globorotalia exilis/miocenica Zone of Bolli, 1970 and render themselves suitable as zonal markers or as datum levels. To bring the Pliocene zones of the Caribbean 


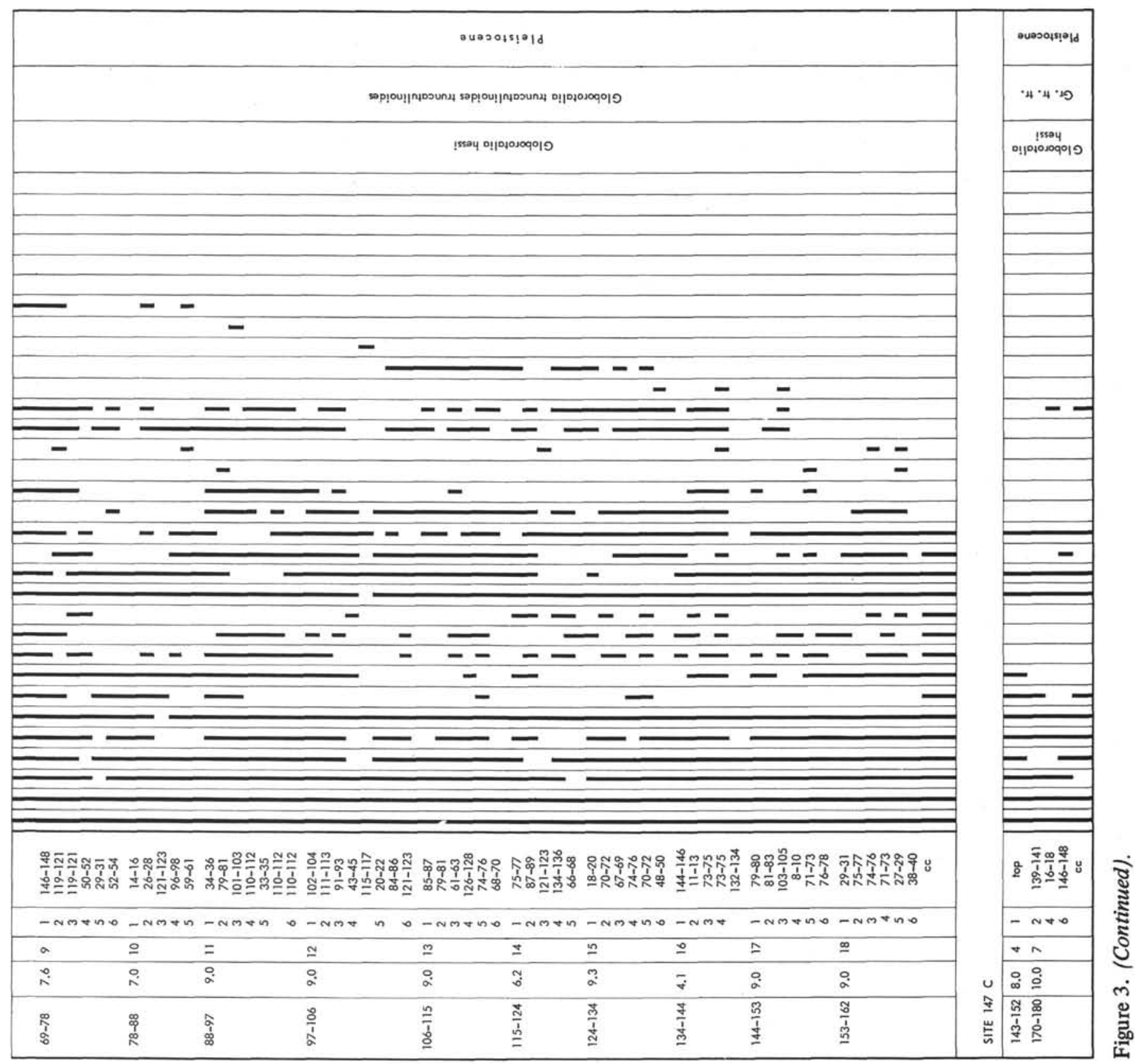

sites to more equal thicknesses and duration, and to offer still closer correlation possibilities, the Globorotalia exilis/ miocenica Zone is here divided, like the Globorotalia margaritae Zone, into two subzones, a lower Globigerinoides trilobus fistulosus Subzone and an upper Globorotalia exilis Subzone. For simplification of nomenclature and to avoid confusion with the exilis Subzone, the zonal name is changed from Globorotalia exilis/miocenica to Globorotalia miocenica Zone, consequently its definition, but not its extension, had to be modified slightly.

\section{Globorotalia miocenica Zone}

Definition: Interval with the zonal marker, between extinction of Globorotalia margaritae evoluta and the extinction of Globorotalia miocenica.

Remarks: The zone was originally defined in Leg 4 Initial Report, p. 586 as the interval with Globorotalia exilis and/or Globorotalia miocenica between the extinction of Globorotalia margaritae and the extinction of the two zonal markers. Further investigations of the extinction level of the two zonal markers has shown that scarce specimens of Globorotalia exilis survive $G$. miocenica in the Caribbean sections by a short time (in Site 31 by $0.5 \mathrm{~m}$, in Site 148 by approximately $1 \mathrm{~m}$, and in Hole $154 \mathrm{~A}$ by as much as about $6 \mathrm{~m}$ ). This, and the subdivision into two subzones, has required a redefinition of the zone.

\section{Globigerinoides trilobus fistulosus Subzone}

Definition: Interval with subzonal marker, between the extinction of Globorotalia margaritae evoluta and the extinction of the subzonal marker.

Remarks: The subzonal marker Globigerinoides trilobus fistulosus commences in most examined sections at the base of the subzone. Only in Hole 154A has it been noted as 
being already in the upper part of the underlying Globorotalia margaritae evoluta Subzone. It must be stressed that only typical Globigerinoides trilobus fistulosus with long and distinct fistules such as is shown in Leg 4 Initial Report, p. 627, pl. 1, figs. 8-11, are to be taken as subzonal markers. Globigerinoides trilobus of fistulosus (Leg 4 Initial Report, p. 627, pl. 1, figs. 6,7) with indistinct and short fistules has a longer range, extending to Recent. In several of the Caribbean sites, Globigerinoides obliquus extremus was found to have about the same extinction level as Globigerinoides trilobus fistulosus (Sites 29, 31, 154 (154A): in others it may continue into the overlying Globorotalia exilis Subzone (Site 148). Globoquadrina altispira altispira, a somewhat erratic form in the Caribbean Pliocene, has a similar maximum extension as Globigerinoides trilobus fistulosus and G. obliquus extremus (Site 31). In some sites it disappears within the Globigerinoides trilobus fistulosus Subzone (Site 30); in others, at the base of it (Site 29) or even high in the Globorotalia margaritae evoluta Subzone (Hole 154A). Globorotalia multicamerata and G. miocenica disappear in the lower part of the Subzone, Sphaeroidinellopsis subdehiscens s.l. and Globorotalia pertenuis somewhat higher.

\section{Globorotalia exilis Subzone}

Definition: Interval with zonal marker, from the extinction of Globigerinoides trilobus fistulosus to the extinction of Globorotalia miocenica.

Remarks: The zonal marker Globorotalia exilis may extend slightly above G. miocenica whose extinction is here taken to indicate the top of the subzone. G. miocenica is usually fairly common up to the point of extinction while $G$. exilis becomes scarce, in particular so in the interval exceeding above $G$. miocenica. Globorotalia inflata $A$ disappears within the subzone (Site 148, 154A).

\section{Globorotalia truncatulinoides ef tosaensis Zone}

The zone is retained as proposed in the Leg 4 Initial Report, p. 587. All that is necessary is a slight alteration in the zonal definition to bring it in line with the change of the underlying Globorotalia miocenica Zone. It now reads: "Interval from extinction of Globorotalia miocenica to first occurrence of G. truncatulinoides truncatulinoides."

\section{Pleistocene-Holocene Zones}

The Globorotalia truncatulinoides truncatulinoides Zone, defined by the total range of the zonal marker and used in the Leg 4 Initial Report, comprises the entire Pleistocene and Holocene. Blow, 1969, distinguished within the Pleistocene-Holocene a Globorotalia truncatulinoides truncatulinoides Zone and a Globigerina calida calida/ Sphaeroidinella dehiscens excavata Zone, with the markers of the latter restricted to it.

From absolute age determinations in Site 147, Globigerina calida calida ranges up from Core 8(CC), about 140,000 years ago or well within the younger Pleistocene. In other Caribbean sites Sphaeroidinella dehiscens excavata also extends considerably downwards into the Pleistocene. Therefore, Blow's criteria can not be used to distinguish the Holocene from the Pleistocene. Instead, the first occurrence of Globorotalia fimbriata and of "modern" G. menardii cultrata (Emiliani, 1969) in Core 2, Section $2(74-76 \mathrm{~cm})$ in Site 147 (approximately 11,000 years ago) offer-at least locally-better criteria for delineating the Pleistocene/ Holocene boundary based on planktonic foraminifera.

Distinct events in the younger Pleistocene of Site 147 are the extinction of Globorotalia tumida flexuosa in Core 6, Section 1 (top) ( $42.00 \mathrm{~m}$ ), approximately 80,000 years ago, and the first appearance of Globigerina calida calida in Core $8(\mathrm{CC})(69.00 \mathrm{~m})$, approximately 140,000 years ago. These events allow subdivision of the Pleistocene from the 140,000 year mark to the Holocene boundary into two subzones, and also give a Holocene subzone.

At present, the remaining Pleistocene, of approximately 1.76 million years duration, from base Globorotalia truncatulinoides truncatulinoides (taken at 1.9 m.y.) to base Globigerina calida calida $(140,000 \mathrm{y}$.) cannot be further subdivided. One distinct level in the lower part of the Pleistocene is the appearance of Globorotalia hessi, which was described as $G$. crassaformis $B$ in the Leg 4 Initial Report. This approximately coincides with the extinction level of Globorotalia crassaformis viola. These events are here used to distinguish a lower Globorotalia crassaformis viola Subzone from a Globorotalia hessi Subzone, which underlies the Globigerina calida calida Subzone.

Consequently, it is possible to subdivide the Pleistocene into four subzones. Of these, the Globorotalia hessi Subzone, apparently, has by far the longest duration, probably in the neighborhood of 1 million years. This subdivision of the Pleistocene, and the separation from it of the Holocene, is based on Site 147 with its high sedimentation rate (approximately $50 \mathrm{~cm}$ per $1000 \mathrm{y}$.) and several other Caribbean sections (see Figure 12).

\section{Globorotalia truncatulinoides truncatulinoides Zone}

Definition: Range of zonal marker.

Remarks: The definition is slightly altered in its wording compared with Bolli 1966a, which, however, does not change the extent of the zone.

\section{Globorotalia crassaformis viola Subzone}

Definition: Interval from first occurrence of Globorotalia truncatulinoides truncatulinoides to first occurrence of Globorotalia hessi.

Remarks: The extinction of the subzonal marker, which ranges up from the Globorotalia miocenica Zone was found in the Caribbean DSDP sites to occur slightly below the first occurrence of Globorotalia hessi. The subzone represents the basal part of the Globorotalia truncatulinoides truncatulinoides Zone.

\section{Globorotalia hessi Subzone}

Definition: Interval with subzonal marker, from its first occurrence to first appearance of Globigerina calida calida.

Remarks: Globorotalia hessi is described as new in this report. In the Leg 4 Initial Report it was figured as Globorotalia crassaformis B. Globigerina calida praecalida becomes extinct at the top of the subzone. 


\section{Globigerina calida calida Subzone}

Definition: Interval with subzonal marker, from its earliest appearance to the extinction of Globorotalia tumida flexuosa.

Remarks: The zonal marker continues to Recent. According to Emiliani, 1969, and Ericson, Ewing, Wollin \& Heezen, 1961, Globorotalia tumida flexuosa, which determines the top of the subzone, represents a good datum level for the Caribbean and Atlantic. Absolute age determinations in Site 147 indicate approximately 140,000 years for the bottom, and about 80,000 years for the top of the subzone.

\section{Globigerina bermudezi Subzone}

Definition: Interval with subzonal marker, from last occurrence of Globorotalia tumida flexuosa to the first appearance of Globorotalia fimbriata s.s.

Remarks: The subzonal marker ranges in Site 147 from the uppermost part of the Globorotalia hessi Subzone to Recent. The base of the subzone is about 80,000 years, the top (Pleistocene-Holocene boundary) is approximately 11,000 years, based on Site 147 measurements.

\section{Globorotalia fimbriata Subzone}

Definition: Range of subzonal marker.

Remarks: The subzone represents the last approximately 11,000 years and thus corresponds with the postglacial warming period. The fauna is also characterized by the extensive development of modern Globorotalia cultrata (Emiliani, 1969). (For a discussion of Globorotalia fimbriata s.s. see also Banner \& Blow, 1960).

\section{Pleistocene-Holocene Correlations}

The Pleistocene-Holocene of the continuously cored Caribbean DSDP Sites 29, 147, 148, 149, and Vema piston core 26-119, taken at approximately the location of Site 29, are correlated on Figure 13, based on the present Pleistocene-Holocene subzonation. The following results from this correlation are of particular interest:

1) There is considerable variation in thickness of the Pleistocene-Holocene sediments, ranging from 162 meters in Site 147 (representing the last approximately 300,000 years only) to about 20 meters in Site 29.

2) The first occurrence of Globorotalia hessi (= base of the Globorotalia hessi Subzone) lies in all sites above the first appearance of Globorotalia truncatulinoides truncatulinoides.

3) The extinction of Globorotalia crassaformis viola lies slightly below the base of Globorotalia hessi.

4) Globorotalia hessi and Globorotaloides hexagonus become extinct below the Globorotalia tumida flexuosa top, and within the Globigerina calida calida Subzone in Site 149 and Vema 26-119. The two species disappear simultaneously with Globorotalia tumida flexuosa in Hole $154 \mathrm{~A}$, indicating that the upper part of the Globigerina calida calida Subzone may be missing there. In Site 29, Globorotalia hessi continues slightly above G. tumida flexuosa, which is here scarce and irregular and its real top therefore difficult to determine. In Site 147, Globorotalia hessi is absent probably for ecological reasons.
5) The base of Globigerina calida calida and the top of Globorotalia tumida flexuosa could be established in all sites. Where $G$. tumida flexuosa is present already in the topmost sample of a site, it is likely that it is not necessarily the highest stratigraphic occurrence and that consequently recovery or coring began within the Globigerina calida calida Subzone. This is the case in Sites 29, 148 and Hole $154 \mathrm{~A}$, and, with the exception of some core catcher material from the Globorotalia fimbriata Subzone, also in Site 149. The upper part of the section, representing at least 140,000 years, was thus not recovered from these sites. As shown by the Vema piston core 26-119, taken at approximately the location of Site 29, the youngest subzones are likely to be present in these sites but were simply not recovered.

6) Succession of the three topmost zones, Globigerina calida calida, Globigerina bermudezi and Globorotalia fimbriata, is clearly distinguishable in Site 147, with its much extended Late Pleistocene-Holocene thickness, and in Vema piston core 29-119.

7) It is well known, and was recently pointed out by Moore (1972), that complete and undisturbed recovery of unconsolidated sediments is rare with the present deep-sea drilling techniques. Evidence for this is given by the strongly disturbed sediments even in cores with 100 percent recovery and in the abnormally high rate of zonal boundaries falling between cores. These are indications that coring in fact is not continuous. As shown here with the Vema 26-119 piston core, a reasonably complete and undisturbed sequence of these uppermost meters, normally missed in the DSDP cores, can be recovered by using appropriate techniques.

The Pliocene-Holocene zones, their subzones proposed here, and datum levels of index species, are shown on Figure 2.

\section{DISTRIBUTION OF THE OLIGOCENE TO RECENT FORAMINIFERA IN LEG 15 SITES}

Compared with Caribbean Sites 29 through 31 of Leg 4, the planktonic foraminifera of Leg 15 were investigated in a more selective way. In the report on Leg 4 foraminifera (Bolli, 1970), two kinds of distribution charts were prepared for each of the sites (29 through 31). On one chart are shown the quantitative distribution of practically all planktonic foraminiferal taxa present (as well as of selected other microfossils), the nature of residue, and the preservation of faunas $\left(\mathrm{CaCO}^{3}\right.$ dissolution). A second chart contains the stratigraphically more important taxa, their overall distribution, and where significant, the coiling direction.

Only the second type of chart is used here for those Leg 15 sites where coring was continuous $(147,148,149,154$, 154A). The chart on the Oligocene-Miocene of Site 149, Cores 14 through 30 , also indicates the frequency of planktonic foraminifera, benthonic foraminifera, Radiolaria, sponge spines, fish debris, and the degree of $\mathrm{CaCO}_{3}$ dissolution. For Sites 150, 151, and 153, whose Oligocene to Recent was only spot cored, the planktonic foraminiferal distribution is presented on tables listing the typical taxa for each investigated sample. At Site 152, no cores were taken within the Oligocene-Recent. 
The following abbreviations of genus names are used on Figures 2 through 13:
B. = Beella
C. = Candeina
$\mathrm{Ga}$. = Globigerinita
$\mathrm{Ge}$. = Globigerinatella
$\mathrm{Gg}$. = Globigerina
Gl. = Globigerinella
Go. = Globorotaloides
Gq. = Globoquadrina
Gs. = Globigerinoides

Gr. = Globorotalia

$\mathrm{H}$. = Hastigerina

Ha. = Hastigerinella

N. = Neogloboquadrina

Pr. = Praeorbulina

$\mathrm{Pu}$. = Pulleniatina

Sa. $=$ Sphaeroidinella

Ss. $=$ Sphaeroidinellopsis

Coiling directions for species of Globorotalia, Globoquadrina, and Pulleniatina are indicated on the distribution charts, Figures 3 through 11, as follows: Line on left side of column $=$ sinistral; Line in center $=$ random; and Line on right side $=$ dextral. The coiling direction on Figures 7 through 9 is indicated by a (r) for dextral and (1) for sinistral.

\section{Site 146}

(Hole 146: $15^{\circ} 06.90^{\prime} \mathrm{N}$; $69^{\circ} 22.67^{\prime} \mathrm{W}$; Hole $146 \mathrm{~A}$ : $15^{\circ} 06.99^{\prime} \mathrm{N} ; 69^{\circ} 22.74^{\prime} \mathrm{W}$ )

Site 146 is located adjacent to Site $149(1.5 \mathrm{~km})$ in the center of the Venezuela Basin and about $40 \mathrm{~km}$ north of Site 29 of Leg 4. Water depth is 3949 meters (approximately $325 \mathrm{~m}$ shallower than Site 29).

Coring operations at Hole 146 resulted in spot Cores 1 and 2 at 96 to 105 meters and 254 to 263 meters, respectively, and continuous coring from 406 to 762 meters (Cores 3 through 44). The interval 701 to 762 meters (Cores 36-44) was drilled with a new bit after successful re-entry. 145.6 meters $(39 \%)$ of the 374 meters cored were recovered. Hole $146 \mathrm{~A}-\mathrm{a}$ missed re-entry attempt-was drilled to 96 meters with a core taken at 87 to 96 meters.

Only the two spot cores at 96-105 meters and 254-263 meters are from the Oligocene-Recent interval. In Core 1, Sections 1 through 6 of Hole 146, foraminifera are virtually absent. The presence there of fish debris indicates deposition below compensation depth. The core catcher sample, however, contains a rich planktonic fauna with Neogloboquadrina dutertrei humerosa, Globorotalia acostaensis, Globigerina nepenthes, Globigerinoides canimarensis, Globoquadrina altispira, etc., indicative for the Late Miocene Neogloboquadrina dutertrei Zone. However, judging from the lithology of Sections 1 through 6 and comparing with Site 149, this core is to be placed instead in the Globorotalia acostaensis Zone and the rich core catcher fauna is to be regarded as contamination.

Section 1 to the upper part of Section 4 of Core 2 contains a rich planktonic foraminiferal fauna with Globorotalia kugleri, G. mayeri, Globigerinita dissimilis, and very scarce Globigerinoides primordius. Some benthonic species occur with the planktonic forms and Radiolaria are abundant throughout. The interval is assigned to the Early Miocene Globigerinoides primordius Zone. The lower part of Section 4, together with Sections 5 and 6, contain large-sized and thick-walled benthonic foraminifera, abundant Radiolaria, but no planktonic foraminifera. The absence of planktonic, and the strong reduction in benthonic, foraminifera is ascribed to $\mathrm{CaCO}_{3}$ dissolution. Core 2 consists essentially of broken lumps of varying lithologic composition within a soupy mass. In comparison with Site 149 , these lumps probably originate from higher in the section, approximately 195 to 223 meters, which corresponds with the Globigerinoides primordius Zone in Site 149.

\section{Site 149}

$\left(15^{\circ} 06.25^{\prime} \mathrm{N} ; 69^{\circ} 21.85^{\prime} \mathrm{W}\right)$

Site 149 is located adjacent $(1.5 \mathrm{~km})$ to Site 146 in the center of the Venezuela Basin. Water depth is 3972 meters (approximately $300 \mathrm{~m}$ shallower than Site 29). See Figures 4 and 5.

Coring was continuous (43 cores) to 390 meters with 239.9 meters $(57 \%)$ recovery. Core 1 recovered only some core catcher material of Holocene age, Cores 2 through 5 penetrated 37 meters of Pleistocene rich in planktonic foraminifera, some of Globigerina calida calida but most of Globorotalia hessi Subzone age. The recovered sediments in Cores 6 through 11 , from 37 to 93 meters, are so strongly disturbed and mixed that zoning of this interval is impossible despite the rich faunas. The interval can therefore be placed anywhere from within the Globorotalia truncatulinoides truncatulinoides Zone to the Neogloboquadrina dutertrei Zone. Sediments in Cores 12 through 30 are hardly disturbed. The planktonic foraminifera are strongly affected by dissolution in many intervals, and Radiolaria become progressively more dominant from the lower part of the Early Miocene downward. However, it was still possible to determine most of the established zones from Oligocene to late Miocene. Not recognized were the Oligocene Cassigerinella chipolensis/Hastigerina micra, Globigerina ampliapertura, and Globigerina ciperoensis ciperoensis zones, and the Miocene Globorotalia fohsi robusta Zone. The Globigerinoides ruber Zone established in Java is so far unknown from the Caribbean region and was also not seen in the Leg 15 sections.

\section{Comparison of the Oligocene-Holocene Planktonic} Foraminiferal Distribution in Sites 29 and 149

"One of the prime objectives of the Caribbean sites was to recover continuous or near continuous cored sections for biostratigraphic investigations from an area where uninterrupted sedimentation was supposed to have taken place" (Leg 4 Initial Report, p. 591).

Though situated in a water depth of 4247 meters, where some $\mathrm{CaCO}_{3}$ dissolution effects were expected, Site 29, in the central part of the Venezuela Basin, was thought to be a favorable location to reach this objective. In fact, from the surface and well into the Pliocene little or no solution effects were observed. Towards the lower Pliocene, however, they begin to rapidly increase. Most of the sediments, considered Late Miocene, from then on consist of brown clay largely void of calcareous remains. Planktonic foraminifera are present again in irregular intervals in the much reduced Early and Middle Miocene. Chalky sediments with faunas assigned to the Globigerinita dissimilis Zone were found in the recovered sections. They rest on Eocene radiolarian ooze.

At intermittent intervals of the Middle Miocene, during Globorotalia fohsi fohsi time and more distinctly during Praeorbulina glomerosa and Globigerinatella insueta Zone 


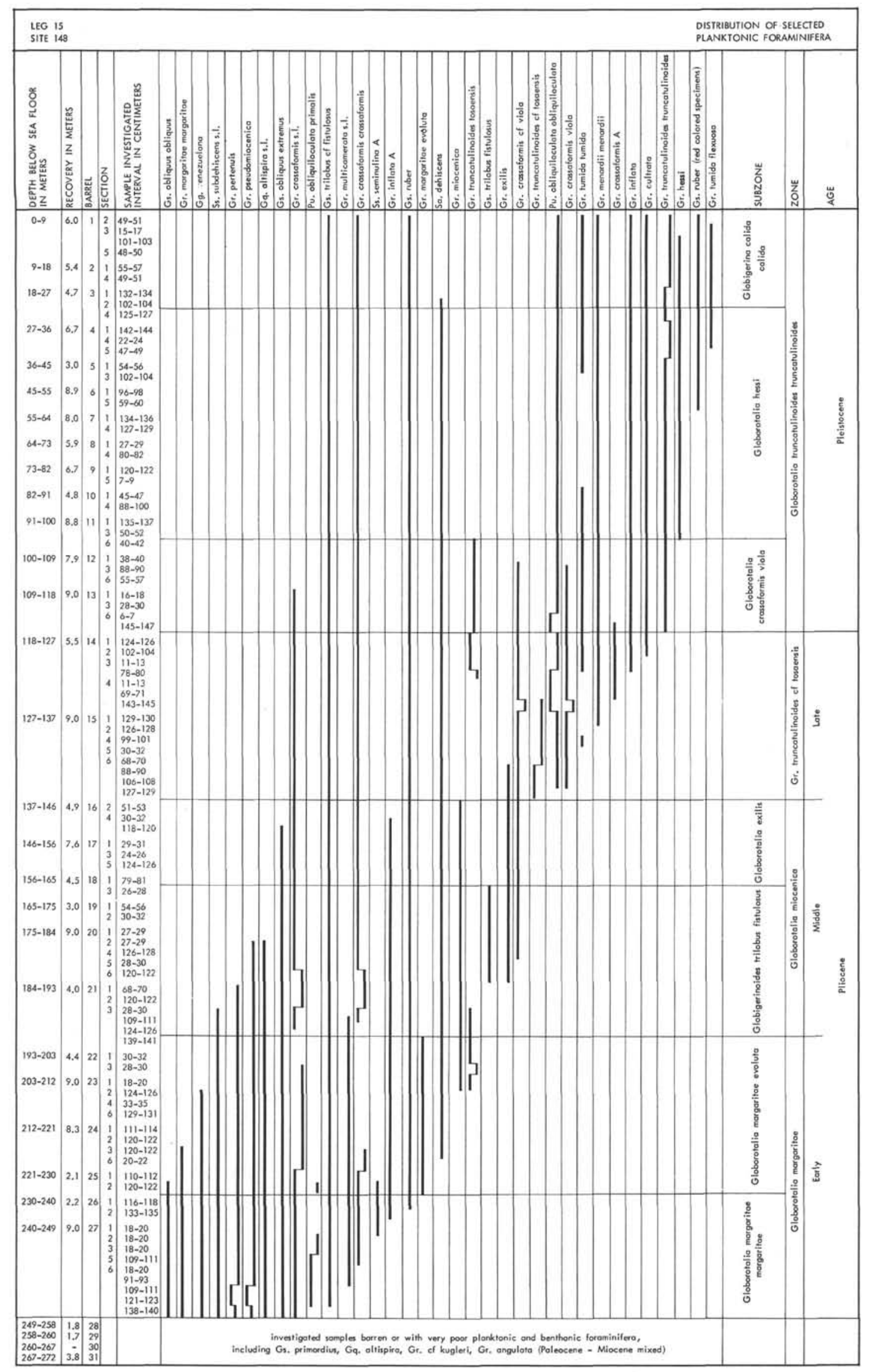

Figure 4. Site 148. 


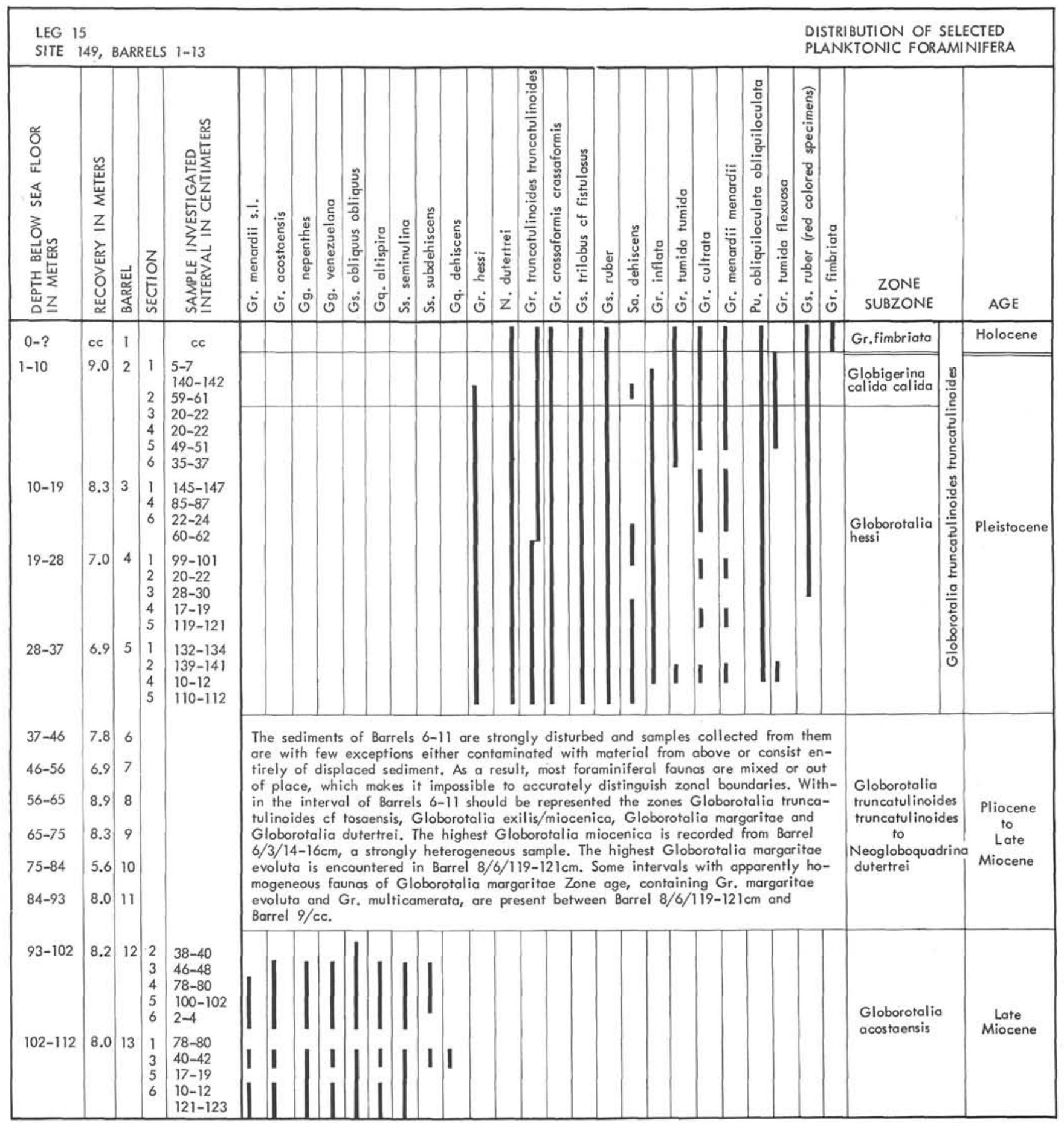

Figure 5. Site 149, Late Miocene to Holocene.

time, sediments were less affected by $\mathrm{CaCO}_{3}$ dissolution than in the Late Miocene.

Though the results from Site 29 were not particularly encouraging for the recovery in the area of a stratigraphically complete Oligocene-Holocene sequence, it was decided to return to Site 146 after Sites 147 and 148 had been drilled, and to core continuously at Site 149 the part above Layer A, which was only spot cored in Site 146.

The biostratigraphy and thickness of zones based on planktonic foraminifera of Sites 29 and 149 is compared on
Figure 6. The interval from sea bottom to the top of the radiolarian ooze in the Eocene measures 270 meters in Site 149 or approximately 150 meters more than in Site 29 . The Pleistocene $(+25 \mathrm{~m})$ and the Oligocene/Early Miocene $(+75 \mathrm{~m})$ account for a part of this difference. The remaining additional 50 meters are mainly attributable to a thicker and biostratigraphically more recognizable Middle Miocene.

The Oligocene-Holocene of Sites 29 and 149 is closely comparable in lithology and faunal content, but Site 149 



Figure 6. Site 149, Middle Oligocene to Late Miocene. 
has recovered a more complete sequence of zones. Rich planktonic foraminiferal faunas characterize the Pleistocene in both sites. They continue into the Pliocene but diminish rapidly towards its base.

Late, and much of the Middle, Miocene are also strongly affected by $\mathrm{CaCO}_{3}$ dissolution, making it difficult or impossible to use planktonic foraminifera for zonal subdivision. Their fairly continuous and frequent occurrence in the Early Miocene are the result of a chalky facies, where in both sites the Praeorbulina glomerosa and Globigerinatella insueta zones, and to a lesser extent the Globigerinita stainforthi and Globigerinita dissimilis zones are recognized.

No planktonic foraminifera indicative of Oligocene were found in Site 29. This was taken in the Leg 4 Initial Report as an indication that possibly parts of the Miocene and probably all of the Oligocene are missing there. Basal Early Miocene and two zones from the Middle and Late Oligocene were recovered from Site 149, making the sequence more complete.

Since most of the zones missing in the cores recovered from Site 29 were recognized at Site 149, a virtually continuous, though partially much condensed, OligoceneHolocene sequence is likely to exist in the central part of the Venezuela Basin (Figure 3). The few zones not recognized in Sites 29 and 149 may have been missed because of $\mathrm{CaCO}_{3}$ dissolution effects, possible disturbance through drilling and because of incomplete recovery.

\section{Site 147}

$\left(10^{\circ} 42.48^{\prime} \mathrm{N} ; 65^{\circ} 10.48^{\prime} \mathrm{W} ; 147 \mathrm{~A}-\mathrm{C}: 10^{\circ} 42.68^{\prime} \mathrm{N}\right.$; $\left.65^{\circ} 10.45^{\prime} \mathrm{W}\right)$

The site is located on the north side of the saddle in the Cariaco Basin; a structural depression on the continental shelf of Venezuela, surrounded by water less than 200 meters deep. It is on the north side of the saddle that divides the east-west running trench into two flat-floored basins of less than 1400 meters depth. Water depth is 892 meters.

At Hole 147 there was continuous coring to 162 meters (Cores 1 through 18) with a recovery of 119.2 meters (74\%). At Hole 147A (pore water and geochemistry program), there were two cores to 13 meters with 6.5 meters (50\%) recovery. At Hole 147B (geochemistry program), there was continuous coring to 115 meters (Cores 1 through 12) with 81 meters recovery (70\%); it was drilled to 125 meters. Hole $147 \mathrm{C}$ (geochemistry program), which was drilled to 116 meters, cored 73 meters to 189 meters (Cores 1 through 8 ) with a recovery of 32.1 meters (40\%).

Sediments laid down largely under anaerobic conditions and rich in well-preserved planktonic foraminifera were continuously cored to 162 meters in Site 147. Composition of the planktonic foraminiferal fauna throughout the section differs in some aspects from that of the open Caribbean and is peculiar to the enclosed water mass of the Cariaco Basin. Absolute age measurements place the Pleistocene-Holocene boundary of approximately 11,000 years at Core 2, Section 2 and the bottom of the hole at approximately 300,000 years. The 162 meters of this section thus represent only the uppermost part of the
Pleistocene. Drilling at this site had to be stopped early because of the steadily increasing gas pressure.

Repeated fluctuations throughout the section of warmand cold-water planktonic foraminifera made the site worthy of detailed investigation. Further, the abundant and well-preserved planktonic foraminifera are well suited for morphologic variability studies of a number of species and for detailed study of the changes in faunal composition.

The results of these investigations are presented in a separate paper of this Volume (Rögl and Bolli). The climatic changes inferred from the planktonic foraminiferal record are shown there on Figure 7. Correlations with climatic changes in the Pleistocene of Sites 148 and 154 (154A), with Emiliani's (1966) paleotemperature scale, and Ericson and Wollin's (1968) warm- and cold-water subdivision, stages, and absolute ages are given on Figure 3 of that article. Taxonomy of the Site 147 planktonic foraminifera is also discussed in the Rögl and Bolli paper, where test and chamber surface variabilities are demonstrated on Plates 1 through 17. A distribution chart of selected planktonic foraminiferal species and the zonation of Site 147 are given on Figure 7 of this report. A chart containing all the taxa examined and their frequency throughout Site 147 is presented on Figure 8 of the Rögl and Bolli paper.

\section{Site 148}

$\left(13^{\circ} 25.12^{\prime} \mathrm{N} ; 63^{\circ} 43.25^{\prime} \mathrm{W}\right)$

This site is located on the western crest of Aves Ridge, about $300 \mathrm{~km}$ west of St. Vincent. It is near the sharp crest of the reflector rising abruptly from the Venezuela Basin, to deepen and disappear to the East. Water depth is 1232 meters. There was continuous coring (31 cores) to 272 meters with $181.8 \mathrm{~m}(66 \%)$ recovery. Pleistocene and Pliocene, well documented by planktonic foraminifera were recovered to approximately 249 meters (Figure 8 ). From this depth to the bottom at 272 meters, samples are barren or very poor in heterogeneous planktonic and benthonic foraminifera of Paleocene, Oligocene, and Miocene age.

The foraminiferal faunas in the marls, calcareous clays, and intermittent ash beds of Cores 1 through 27 are mostly rich, consisting almost exclusively of planktonic forms (Figure 9). $\mathrm{CaCO}_{3}$ dissolution effects are absent or insignificant throughout this interval.

An abrupt change in lithology takes place between Cores 27 and 28, at approximately 249 meters. Cores 28 through 31 consist of disturbed clays, silts, sands, breccias, and ash; all are of varying color. Investigated samples from this interval proved to be either barren or to contain very poor heterogeneous planktonic and benthonic foraminiferal faunas ranging in age from Paleocene to Miocene. Present in Cores 28 through 31 are Globigerinoides primordius, $G$. ?bisphericus, Globoquadrina altispira, Globorotalia cf kugleri; all are indicative of Early Miocene. Globorotalia angulata and Bathysiphon sp, some very large in size, are of Paleocene age. Similar large-sized Bathysiphon are known from the Lower Scotland Formation of Barbados. Buliminas with smooth surface features are present in Cores 29 through 31 ; pieces of carbonized plant material are in Core 29, Section 1 (95-98 cm). 


\begin{tabular}{|c|c|c|c|c|c|c|c|}
\hline 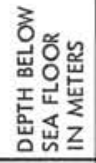 & 竎 & 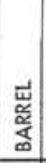 & $\begin{array}{l}z \\
\text { ․ } \\
\text { w } \\
\text { n }\end{array}$ & 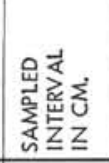 & DIAGNOSTIC PLANKTONIC FORAMINIFERA & ZONE & AGE \\
\hline \multirow[t]{2}{*}{ 49-58 } & \multirow[t]{2}{*}{9.0} & \multirow[t]{2}{*}{1} & \multicolumn{2}{|r|}{$\begin{array}{l}98-100 \\
139-141\end{array}$} & $\begin{array}{l}\text { Gr. miocenica, Gr. exilis, Gr. crassaformis s.l., Gs. trilobus fistulosus, Gs. obliquus extremus, } \\
\text { Sa. dehiscens }\end{array}$ & $\begin{array}{l}\text { Globorotalia } \\
\text { miocenica }\end{array}$ & $\begin{array}{l}\text { Middle } \\
\text { Pliocene }\end{array}$ \\
\hline & & & 3 & $\begin{array}{c}139-141 \\
66-68 \\
145-147\end{array}$ & $\begin{array}{l}\text { Gr. margaritae evoluta, Gr. multicamerata, Gr. pertenuis, Gr. pseudomiocenica, Gr. miocenica, } \\
\text { Gr, truncatulinoides tosaensis (r), Gr. crassaformis s.I. (r), Gs. obliquus extremus, Sa. dehiscens } \\
\text { Gr. margaritae evoluta, Gr. multicamerata, Gr. pertenuis, Gr. pseudomiocenica, Gr. crassaformis s.l. } \\
\text { (r), Gs. obliquus extremus, Ss. subdehiscens, Sa. dehiscens } \\
\text { Gr. multicamerata, Gr. pertenuis, Gr. crassaformis s.l. (I), Gs. obliquus extremus, Ss. subdehiscens, } \\
\text { Ss. seminulina A, Sa. dehiscens }\end{array}$ & $\begin{array}{l}\text { Globorotalia } \\
\text { margaritae }\end{array}$ & $\begin{array}{l}\text { Early } \\
\text { Pliocene }\end{array}$ \\
\hline $77-86$ & 9.0 & 2 & 2 & $\begin{array}{c}118-120 \\
c c \\
69-71\end{array}$ & $\begin{array}{l}\text { below compensation depth: fish remains, practically no planktonic foraminifera } \\
\text { below compensation depth: minute yellow/brown dolomite crystals } \\
\text { do. }\end{array}$ & ? & $?$ \\
\hline $86-95$ & 8.0 & \multicolumn{2}{|c|}{3} & cc & $\begin{array}{l}\text { do, but with in addition few specimens of Gr. mayeri, Gq. altispira s.l., Gs. trilobus s.l., Ss. seminu } \\
\text { lina }\end{array}$ & $\begin{array}{l}\text { ? Globorotalia } \\
\text { mayeri }\end{array}$ & $\begin{array}{l}\text { Middle } \\
\text { Miocene }\end{array}$ \\
\hline \multirow[t]{3}{*}{$95-105$} & \multirow[t]{2}{*}{8.6} & \multirow[t]{2}{*}{4} & 1 & $116-118$ & $\begin{array}{l}\text { Gr. fohsi peripheroronda, Gr. mayeri, Ge. insueta, Gg. venezuelana, Gq. altispira s.l., Gq. dehis- } \\
\text { cens, Gs. bisphaericus }\end{array}$ & $\begin{array}{l}\text { Globigerinatel- } \\
\text { la insueta }\end{array}$ & \multirow{3}{*}{$\begin{array}{l}\text { Early } \\
\text { Miocene }\end{array}$} \\
\hline & & & 3 & $0-2$ & strongly affected by solution, mainly fish remains. Ga. dissimilis & ?Ga,dissimilis & \\
\hline & 8.4 & 5 & 5 & $42-44$ & Gr. of kugleri, Gr. mayeri s.l., Ga. dissimilis, Gg. venezuelano, Gs. primordius & Gs. primordius & \\
\hline
\end{tabular}

Figure 7. Site 150.

\begin{tabular}{|c|c|c|c|c|c|c|c|}
\hline 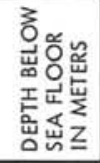 & 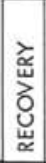 & 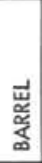 & 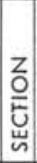 & 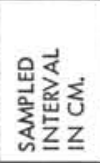 & DIAGNOSTIC PLANKTONIC FORAMINIFERA & ZONE & AGE \\
\hline $61-70$ & 9.0 & 1 & $\begin{array}{l}1 \\
2 \\
4 \\
6\end{array}$ & $\begin{array}{l}10-12 \\
100-102 \\
100-102 \\
118-120\end{array}$ & $\begin{array}{l}\text { Gr. menardii menardii (I), Gr. hessi, Pulleniatina obliquiloculata obliquiloculata ( } r \text { ), Sa. dehiscens } \\
\text { Gr. menardii menardii (I), Gr. hessi, Pulleniatina obliquiloculata obliquiloculata ( } r \text { ), Sa. dehiscens } \\
\text { Gr. truncatulinoides truncatulinoides ( } r \text {, I), Pu. obliquiloculata obliquiloculata ( } r \text { ), Sa. dehiscens } \\
\text { Gr. menardii menardii (I), Gr. truncatulinoides truncatulinoides ( } r) \text {, Gr. crassaformis viola (I), } \\
\text { Pu. obliquiloculata obliquiloculata (I), Sa. dehiscens }\end{array}$ & $\begin{array}{l}\text { Globorotalia } \\
\text { truncatulinoides } \\
\text { truncatulinoides }\end{array}$ & Pleistocene \\
\hline $117-126$ & 4.5 & 2 & $\begin{array}{l}1 \\
2 \\
3\end{array}$ & $\begin{array}{c}84-86 \\
102-104 \\
100-102\end{array}$ & $\begin{array}{l}\text { Gr. margaritae margaritae, Gr. multicamerata s.l., Gr. pertenuis, Gr. pseudomiocenica, Gg. nepenthes, } \\
\text { Gs. obliquus obliquus, Gs. obliquus extremus, Gq. altispira s.I., Ss. subdehiscens, Ss, seminulina A }\end{array}$ & $\begin{array}{l}\text { Globorotalia } \\
\text { margaritae }\end{array}$ & $\begin{array}{l}\text { Early } \\
\text { Pliocene }\end{array}$ \\
\hline \multirow[t]{2}{*}{$181-190$} & 6.9 & 3 & 1 & $6-8$ & $\begin{array}{l}\text { Gr. fohsi lobata, Gr. fohsi fohsi, Gr. mayeri, Gg. venezuelana, Gs. obliquus obliquus, Gs.altiapertura, } \\
\text { Gq. dehiscens, Gq. altispira s.I., Ss. seminulina }\end{array}$ & $\begin{array}{l}\text { Globorotalia } \\
\text { fohsi lobata }\end{array}$ & \multirow{3}{*}{$\begin{array}{l}\text { Middle } \\
\text { Miocene }\end{array}$} \\
\hline & & & $\begin{array}{l}3 \\
6\end{array}$ & $\begin{array}{l}118-120 \\
100-102\end{array}$ & $\begin{array}{l}\text { Gr. fohsi fohsi, Gr. mayeri, Gg. venezuelana. Gs. obliquus obliquus, Gs. altiapertura, Gq. dehiscens, } \\
\text { Gq. altispira s.l., Ss. seminulina }\end{array}$ & $\begin{array}{l}\text { Globorotalia } \\
\text { fohsi fohsi }\end{array}$ & \\
\hline \multirow[t]{5}{*}{$237-246$} & 3.0 & 4 & 1 & $4-8$ & $\begin{array}{l}\text { Gr. fohsi peripheroronda, Gr. fohsi fohsi, Gr. mayeri, Gr. archeomenardii, Gg. venezuelana, } \\
\text { Gq. altispira, Ha. bermudezi, Orbulina sp. }\end{array}$ & $\begin{array}{l}\text { Gr. fohsi } \\
\text { peripheroronda }\end{array}$ & \\
\hline & & & & $23-26$ & $\begin{array}{l}\text { Gr. fohsi peripheroronda, Gr. mayeri, Gr. archeomenardii, Gg. venezuelana, Gq. altispira s.l., } \\
\text { Gq. dehiscens, Ho. bermudezi }\end{array}$ & $\begin{array}{l}\text { ? Praeorbulina } \\
\text { glomerosa }\end{array}$ & \multirow{4}{*}{$\begin{array}{l}\text { Early } \\
\text { Miocene }\end{array}$} \\
\hline & & & & $\begin{array}{l}77-80 \\
125-128\end{array}$ & $\begin{array}{l}\text { Gr. fohsi peripheroronda, Gr. mayeri, Gg. venezuelana, Gq. altispira, Gs. altiapertura, Ga. dissimilis, } \\
\text { Go. stainforthi } \\
\text { Gr. fohsi peripheroronda, Ge. insueta, Gg. venezuelana, Gq. altispira, Gs. altiopertura, Ga. dissimilis, } \\
\text { Gr. mayeri }\end{array}$ & $\begin{array}{l}\text { Globigerinita } \\
\text { stainforthi }\end{array}$ & \\
\hline & & & & $140-143$ & $\begin{array}{l}\text { Gr. peripheroronda, Gr. mayeri, Gg. venezuelana, Gq. altispira, Gs. altiapertura, Ga. dissimilis, } \\
\text { Ga. stainforthi }\end{array}$ & $\begin{array}{l}\text { Ga. stainforthi } \\
\text { or Ga. dissimilis }\end{array}$ & \\
\hline & 2.7 & 5 & 1 & $87-90$ & $\begin{array}{l}\text { Gr. fohsi peripheroronda, Gr. mayeri, Gg. venezuelana, Gq. altispira s.l., Gs. altiaperturo, } \\
\text { Gs. trilobus s.I., Gs, ruber, Ga. dissimilis } \\
\text { Gr. mayeri s.l., Gg. venezuelana, Gq. altispira s.l., Ga. dissimilis, Ga. stainforthi, Gs. altiapertura, } \\
\text { Gs. trilobus s.l., Gs. ruber }\end{array}$ & $\begin{array}{l}\text { Globigerinito } \\
\text { dissimilis }\end{array}$ & \\
\hline $311-320$ & 3.9 & 6 & 2 & $77-80$ & Gr. ef kugleri, Gg. venezuelana, Gg. rohri, Gq. altispira s.l., Ga. dissimilis, Ga. stainforthi & $\begin{array}{l}\text { ? Globorotalia } \\
\text { kugleri }\end{array}$ & \multirow[b]{3}{*}{$\begin{array}{l}\text { Late } \\
\text { Oligocene }\end{array}$} \\
\hline \multirow[t]{2}{*}{$320-329$} & 3.0 & 7 & 1 & $66-70$ & $\begin{array}{l}\text { Gr. ef mayeri, Gg. venezuelana, Gg. sellii, Gg. rohri. Gg. ef triloculinoides, Gq. altispira s.l., } \\
\text { Ga. dissimilis, Ga. unicavus }\end{array}$ & $\begin{array}{l}\text { Gr. kugleri or } \\
\text { Gg. cip. cip. }\end{array}$ & \\
\hline & 0.8 & 8 & 2 & $\begin{array}{l}103-107 \\
\mathrm{cc} \\
75-78\end{array}$ & $\begin{array}{l}\text { Gr. cf. mayeri, Gg. venezuelana, Gg. sellii, Gg. rohri, Gg. ciperoensis ciperoensis, Gg. cf tri- } \\
\text { loculinoides, Gq. altispira s.l., Ga, dissimilis, Ga. unicavus } \\
\text { scarce reworked Paleocene/Lower Eocene planktonic foraminifera (in core catcher only) } \\
\text { Gr. cf mayeri, Gr. opima nana, Gg. venezuelana, Gg. sellii, Gg. rohri, Gg. ciperoensis ciperoensis, } \\
\text { Ga. dissimilis, } \\
\text { scarce reworked Paleocene/Lower Eocene planktonic foraminifera }\end{array}$ & $\begin{array}{l}\text { Globigerina } \\
\text { ciperoensis } \\
\text { ciperoensis }\end{array}$ & \\
\hline $339-348$ & 2.2 & 9 & 2 & $135-138$ & $\begin{array}{l}\text { Gr. opima opima, Gr. opima nano, Gg. ciperoensis ciperoensis, Gg. ciperoensis angul isuturalis, } \\
\text { Gq. altispira s.I. }\end{array}$ & $\begin{array}{l}\text { Globorotalia } \\
\text { opima opima }\end{array}$ & $\begin{array}{l}\text { Middle } \\
\text { Oligocene }\end{array}$ \\
\hline
\end{tabular}

Figure 8. Site 151. 


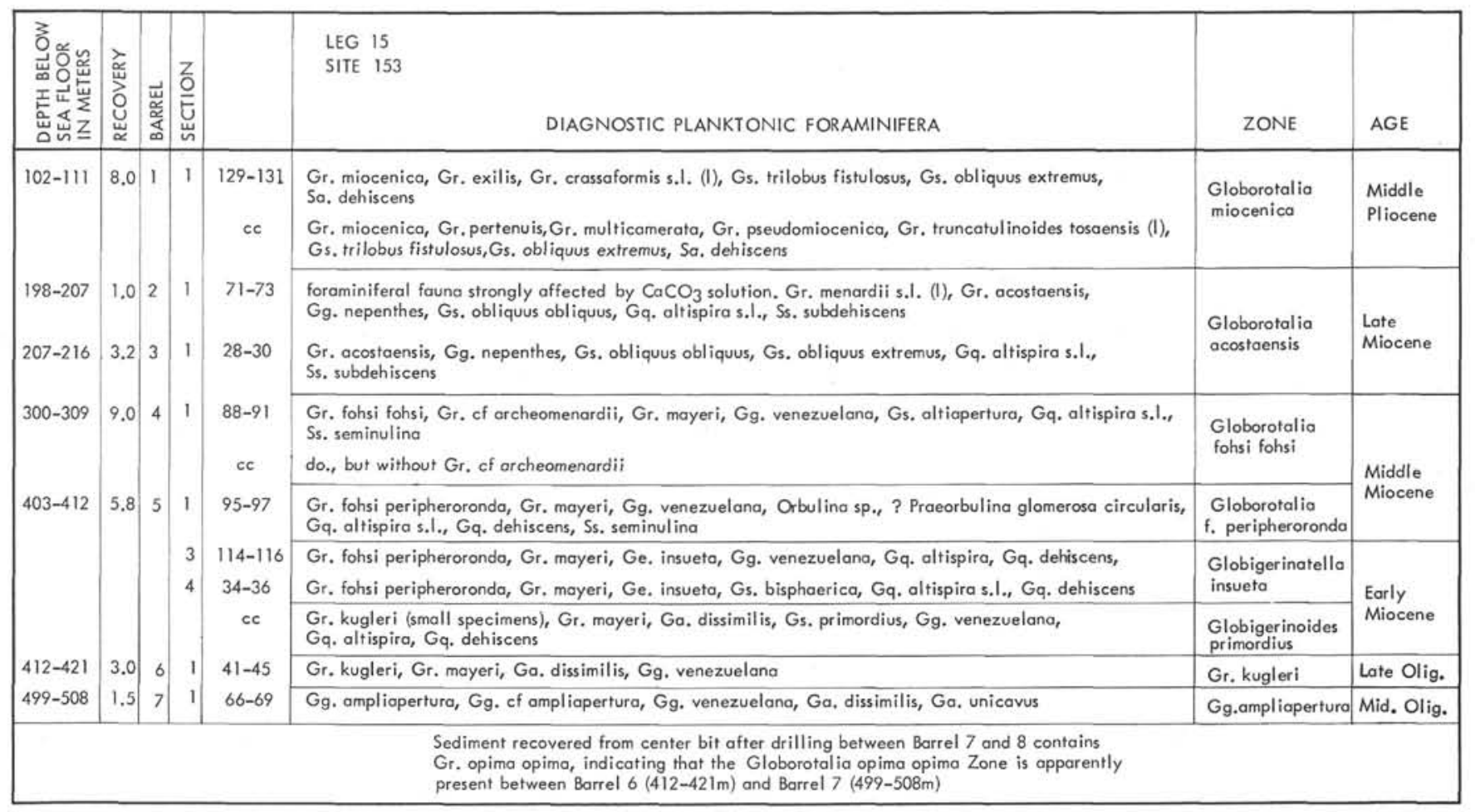

Figure 9. Site 153.

The thickness of approximately 250 meters from Recent into the Early Pliocene Globorotalia margaritae Zone compares with about 370 meters for an equivalent interval in Site 30 of Leg 4, drilled on Aves Ridge some $80 \mathrm{~km}$ to the southeast of Site 148, in a water depth of 1218 meters. The increased thickness in Site 30 is probably largely attributable to the higher content of volcanic material. In contrast to Site 148, which terminated in strongly disturbed and heterogeneous sediments in the lower part of or immediately below the Globorotalia margaritae Zone, Site 30 penetrated a continuous stratigraphic sequence down into the Early Miocene Praeorbulina glomerosa Zone, where it bottomed at 1411 feet or about 500 meters.

The differences between the two sites, both situated in comparatively shallow waters on the southern part of the Aves Ridge, are an indication that its history is complex. This assumption is substantiated by the presence of shallow water Late Oligocene-Early Miocene limestones with algae and Lepidocyclina, dredged from a sea mount on the eastern part of the Aves Ridge $\left(13^{\circ} 30^{\prime} \mathrm{N} ; 63^{\circ} 10^{\prime} \mathrm{W}\right)$ in a water depth of between 620 and 730 meters. This is about $60 \mathrm{~km}$ east of Site 148 and $95 \mathrm{~km}$ north-northeast of Site 30 (Barbieri and Medioli, 1972).

\section{Site $\mathbf{1 5 0}$}

\section{$\left(14^{\circ} 30.69^{\prime} \mathrm{N} ; 69^{\circ} 21.35^{\prime} \mathrm{W}\right)$}

Site 150 is located in the Venezuela Basin, about $35 \mathrm{~km}$ south of Site 29 of Leg 4, where seismic profiles recorded an anomalous thinning of all sediment layers above Horizon B. Water depth is 4545 meters.

Coring in Hole 150 consisted of taking a spot core at 49 to 58 meters and continuous coring from 77 to 114 meters (cores 2-5) and 127 to 180 meters (cores 6-12). Total drilling without cores was 81 meters, and total coring was 99 meters with 39.3 meters ( $40 \%$ ) recovery. Hole 150 A was drilled to 110 meters. Two cores were taken from 110 to 128 meters with a recovery of one meter $(6 \%)$. Hole $150 \mathrm{~A}$ was drilled to sample the interval not.cored in Hole 150.

Core 1, Section 1 contains a rich planktonic foraminiferal fauna, straddling the Pliocene Globorotalia miocenica/Globorotalia margaritae Zone boundary (Figure 10). Section 1 contains a rich fauna, only slightly affected by $\mathrm{CaCO}_{3}$ dissolution. The faunas in Sections 3 and 4 are still fairly rich but become progressively corroded downwards by dissolution effects; they are almost completely destroyed in the core catcher sample of Core 1.

Examined samples of Cores 2 and 3 are entirely barren of foraminifera, the core catcher of Core 3 contains a few specimens indicating a questionable Globorotalia mayeri Zone age. Poor to very poor, almost destroyed planktonic foraminifera, are present in Core 4; only a sample taken at 116 to $118 \mathrm{~cm}$ in Section 1 contains an exceedingly rich fauna of Early Miocene Globigerinatella insueta Zone age.

The lower part of Core 5 again carries a rich planktonic fauna, though damaged by solution effects. It is indicative of the Globigerinoides primordius Zone.

The soupy, heterogeneous contents, including chalky and chert fragments, of Core 1 of $150 \mathrm{~A}$ do not permit a dating based on planktonic foraminifera.

\section{Site 151}

\section{$\left(15^{\circ} 01.02^{\prime} \mathrm{N} ; 73^{\circ} 25.58^{\prime} \mathrm{W}\right)$}

Site 151 is located on the southern part of the Beata Ridge, where a seismic reflection profiler recorded about $0.4 \mathrm{sec}$ reflection of acoustically transparent sediment overlying a single strong reflector. Four cores were taken at 


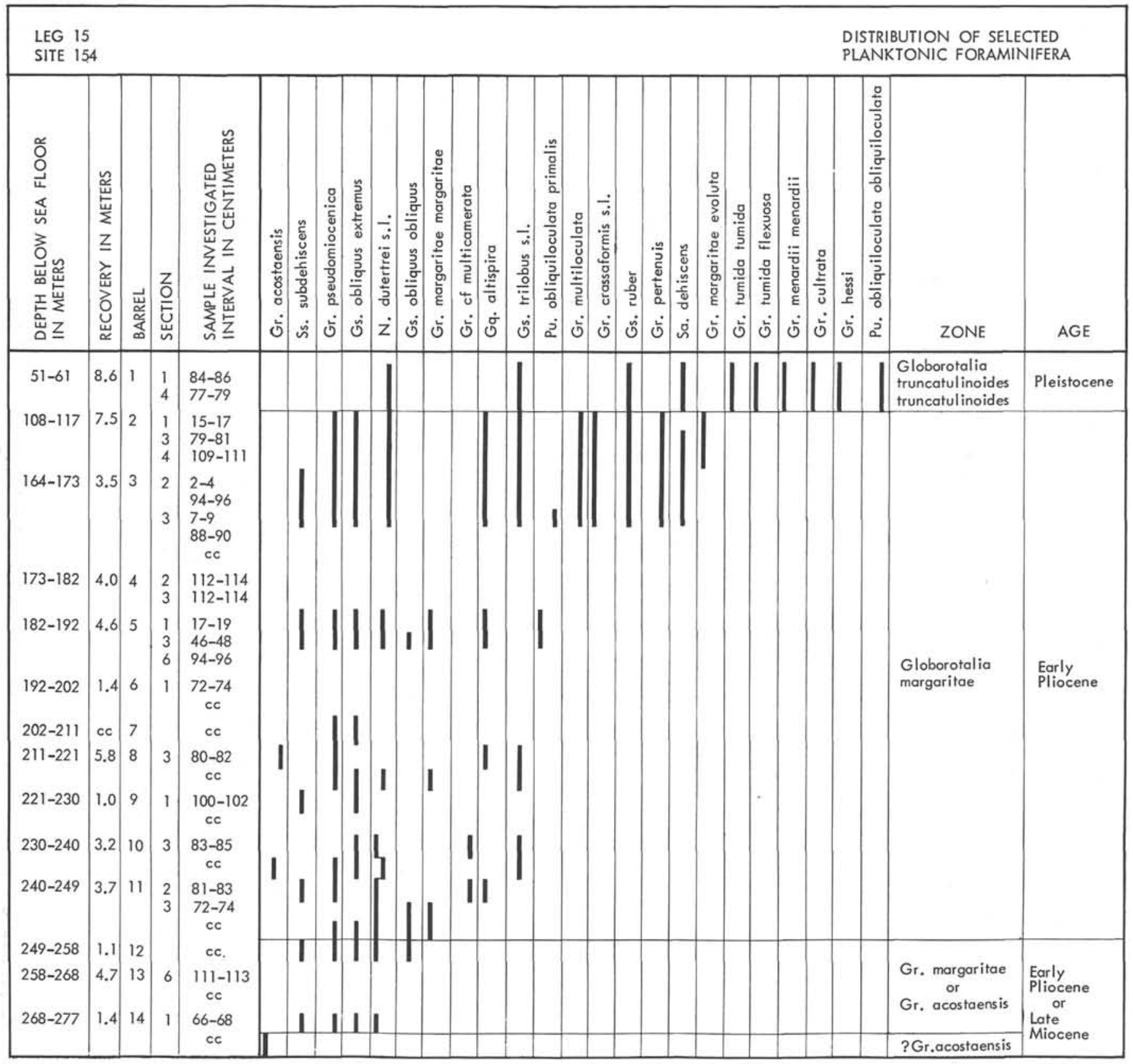

Rich, mainly planktonic foraminiferal faunas are present from Barrel 1 to Barrel $3 / 3 / 7-9 \mathrm{~cm}$. From Barrel $3 / 3 / 88-90 \mathrm{~cm}$ residues consist mainly of volcanics. Samples examined from this interval were found to be either barren, or to contain poor to very poor foraminiferal faunas, mainly of planktonic nature. Their distribution indicates a normal stratigraphic sequence.

Figure 10. Site 154.

about 60 meter intervals from 61 meters to 246 meters. From 302 meters, the section was continuously cored to a total depth of 382 meters. Water depth is 2029 meters.

The four spot cores recovered rich planktonic foraminiferal faunas representing the Pleistocene Globorotalia truncatulinoides truncatulinoides Zone in Core 1, the Early Pliocene Globorotalia margaritae Zone in Core 2, and the Middle Miocene Globorotalia fohsi lobata and Globorotalia fohsi fohsi zones in Core 3 (Figure 11). Section 1 of Core 4 contains fragments of a multitude of zones: Globorotalia fohsi peripheroronda, Praeorbulina glomerosa, Globigerinita stainforthi or Globigerinita dissimilis, while Section 2 is of Globigerinita dissimilis Zone age. The upper part of the continuously cored section from 302 meters down (Cores 5 through 9) comprises the Early Miocene Globigerinita dissimilis Zone to the Middle Oligocene Globorotalia opima opima Zone. Section 2, $(135-138 \mathrm{~cm})$ of Core 9 is of Globorotalia opima opima Zone age but the catcher sample, immediately below, already contains a distinct Early Eocene Globorotalia formosa formosa fauna. Early Oligocene, Late and Middle Eocene and also the uppermost part of the Early Eocene 


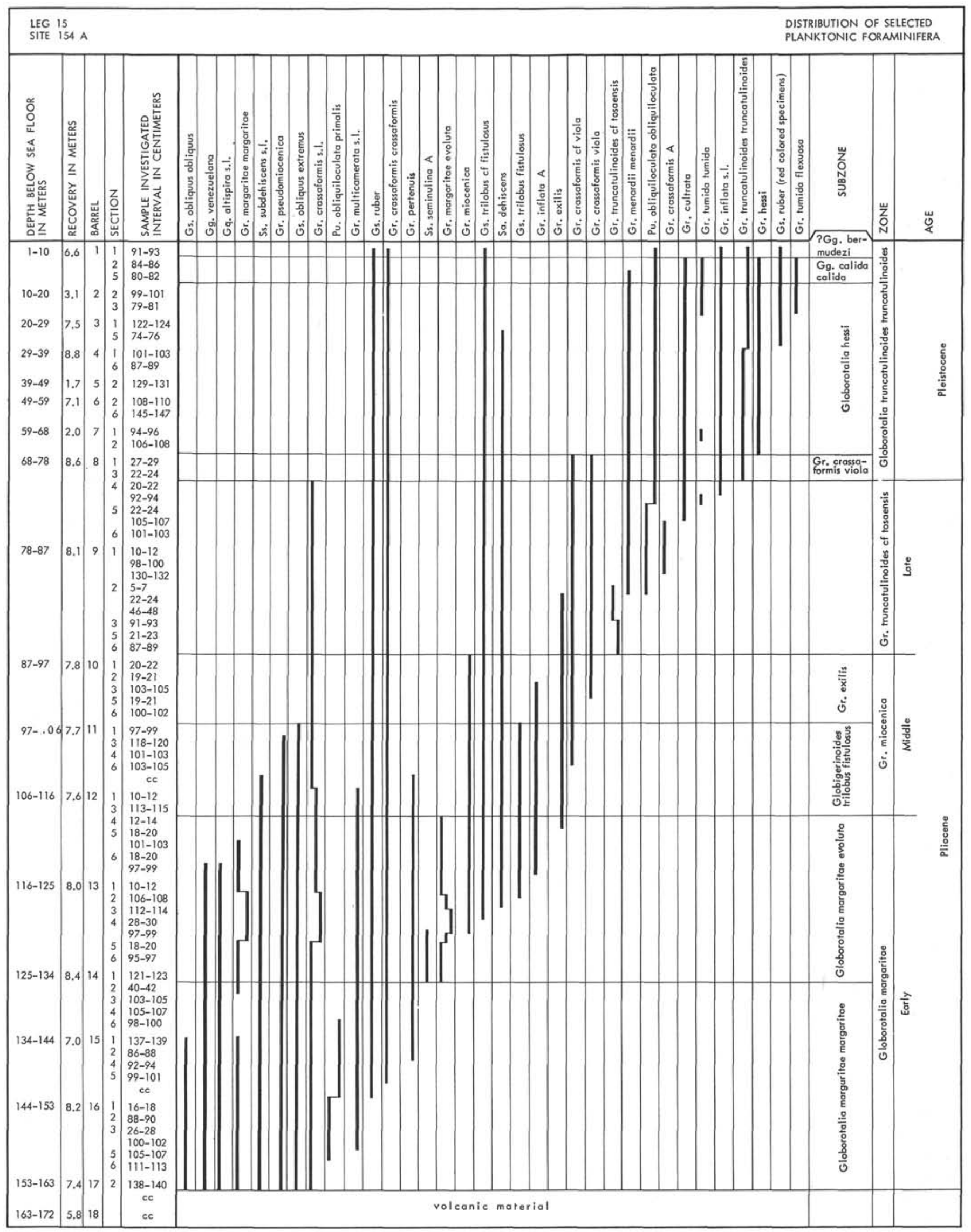

Figure 11. Hole 154A. 
are thus absent in Site 151. It can be concluded from the spot cores and the upper part of the continuously cored section that the Pleistocene, Pliocene, Miocene, Late Oligocene and upper part of the Middle Oligocene are fairly continuous.

\section{Site 153}

\section{$\left(13^{\circ} 58.33^{\prime} \mathrm{N} ; 72^{\circ} 26.08^{\prime} \mathrm{W}\right)$}

Site 153 is located at the southern end of the Beata Ridge where it is terminated by the Aruba Gap. Water depth is 3932 meters.
The Pliocene, Miocene and Oligocene were spot cored at about 100 meter intervals, and an incomplete sequence of zones was obtained (Figure 12). Most samples of the seven spot cores are more or less affected by $\mathrm{CaCO}_{3}$ dissolution. Notable is the presence in Site 153 of the Middle Oligocene Globigerina ampliapertura Zone, which was recognized in Core $7(499-508 \mathrm{~m})$ for the first time in a Caribbean DSDP site. Core 8 taken at 563 to 572 meters is already in the Early Eocene Globorotalia rex Zone. From this it would appear that, as at Site 151, the Late and Middle Eocene are here missing, or are much condensed.

\begin{tabular}{|c|c|c|c|c|c|c|c|c|c|c|}
\hline & & & & SITE & 149 & & & SITE 2 & $9 / 29 B$ & \\
\hline & $A G E$ & ZONE & Barrel & $\begin{array}{l}\text { Interval } \\
\text { in meters }\end{array}$ & $\begin{array}{l}\text { Thickness } \\
\text { in meters }\end{array}$ & $\begin{array}{l}\text { Preser- } \\
\text { vation }\end{array}$ & Barrel & $\begin{array}{l}\text { Interval } \\
\text { in meters }\end{array}$ & $\begin{array}{l}\text { Thickness } \\
\text { in meters }\end{array}$ & $\begin{array}{l}\text { Preser- } \\
\text { vation }\end{array}$ \\
\hline Pleis & tocene & Gr, truncatulinoides truncatulinoides & $1-5$ & $1-5$ & 37 & & $1-2$ & $0-12$ & 12 & \\
\hline & Late & Gr. truncatulinoides tosaens is & & & & & 2 & $12-18$ & 6 & \\
\hline ভ্ّ & Middle & Gr. miocenica & & 2702 & 56 & & $2-4$ & $18-30$ & 12 & \\
\hline a & Early & Gr. margaritae & & & & & 4 & $30-33$ & 3 & + \\
\hline & & N. dutertrei & & & & & $4-6$ & $33-54$ & 19 & $*$ \\
\hline & & Gr. acostaens is & $12-14$ & $93-115$ & 22 & * & B $1-3$ & $57-88$ & 31 & * \\
\hline & & Gr. menardii & $14-15$ & $115-122$ & 7 & $*$ & & & & \\
\hline & & Gr. mayeri & 15 & $122-127$ & 5 & $*$ & & & & \\
\hline & & Gs. ruber & & & & & & & & \\
\hline & Middle & Gr. fohsi robusta & & & & & & & & \\
\hline$\underset{\mathbb{E}}{\stackrel{\Perp}{C}}$ & & Gr. fohsi lobata & 15 & $127-128$ & 1 & * & & & & \\
\hline$\stackrel{\circ}{\sum}$ & & Gr. fohsi fohsi & $15-16$ & $128-136$ & 8 & * & B 4 & $88-91$ & 3 & घ \\
\hline & & Gr. fohsi peripheroronda & $16-17$ & $136-146$ & 10 & 粗 & & & & \\
\hline & & Pr. glomerosa & $17-18$ & $146-158$ & 12 & & B $4-5$ & $91-100$ & 9 & \\
\hline & & Ge. insueta & $18-20$ & $158-176$ & 18 & + & B $5-6$ & $100-115$ & 15 & \\
\hline & Early & Ga. stainforthi & & & & & 7 & & & \\
\hline & & Ga, dissimilis & $20-22$ & נדוד & 17 & \% & 7 & & & \\
\hline & & Gs. primordius & $22-25$ & $195-223$ & 28 & + & & & & \\
\hline & & Gr. kugleri & $26-28$ & $223-251$ & 28 & - & & & & \\
\hline & & Gg. ciperoens is ciperoens is & & & & & & & & \\
\hline 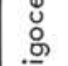 & & Gr. opima opima & $29-30$ & $251-270$ & 19 & ㅂ. & & & & \\
\hline$\overline{\mathrm{O}}$ & & Gg. ampliapertura & & & & & & & & \\
\hline & Early & Ca. chipolensis / Ha. micra & & & & & & & & \\
\hline
\end{tabular}

Foraminifera affected by $\mathrm{CaCO}_{3}$ dissolution:

Figure 12. Comparison of Site 149 with Site 29/29B. 

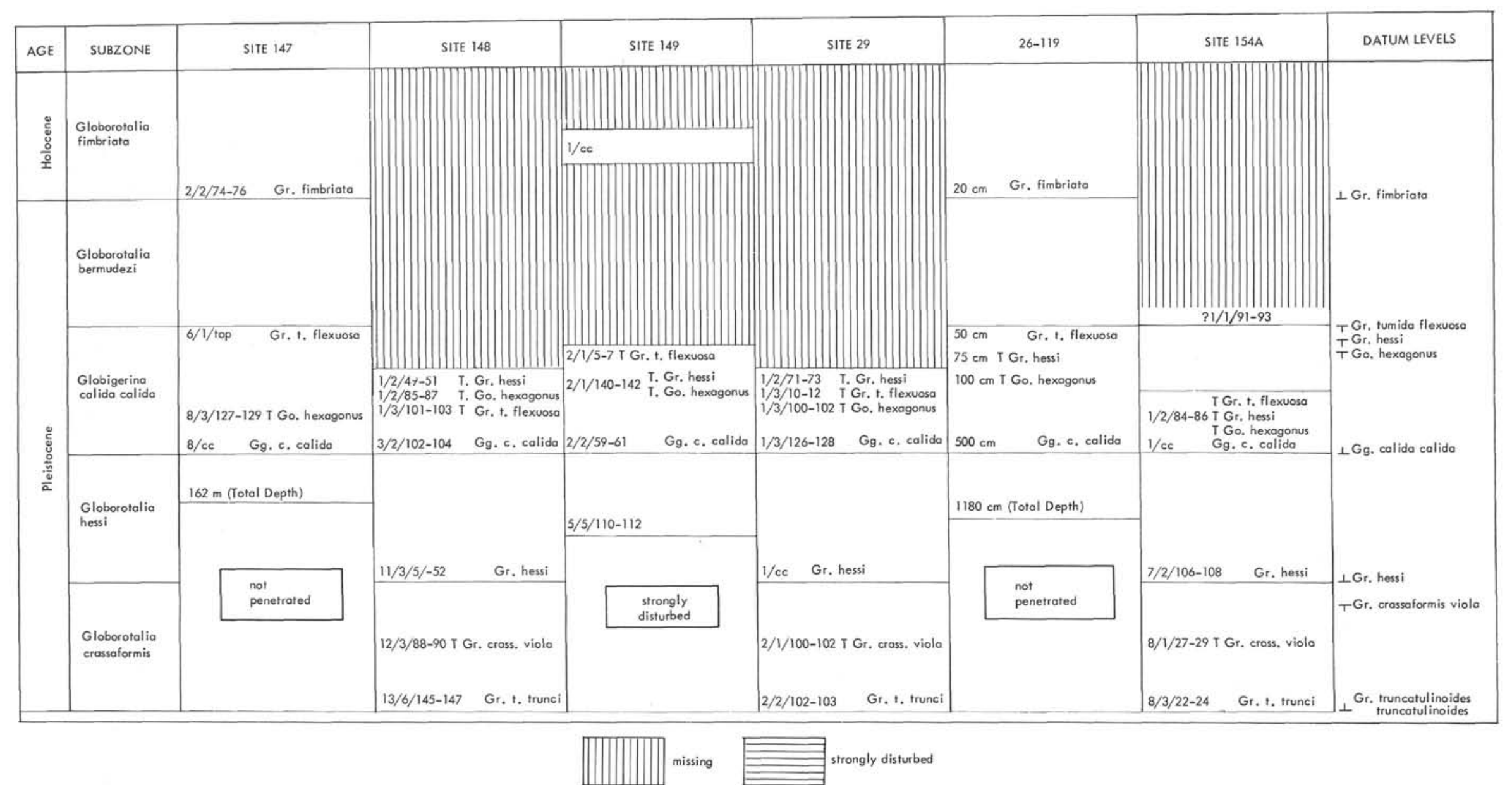

Figure 13. The Pleistocene-Holocene (Globorotalia truncatulinoides truncatulinoides Zone) in the Caribbean Sites 29, 147, 148, 149, 154, 154A and Vema piston core 26-119. 


\section{Site 154}

(Hole 154: $11^{\circ} 05.11^{\prime} \mathrm{N} ; 80^{\circ} 22.82^{\prime} \mathrm{W}$;

Hole $154 \mathrm{~A}$ : $11^{\circ} 05.07^{\prime} \mathrm{N}, 80^{\circ} 22.82^{\prime} \mathrm{W}$ )

The site is located $210 \mathrm{~km}$ north of Cristobal, Panama, on a topographic high that rises above the Colombian Abyssal Plain and displays a section of acoustically transparent sediment overlying an arched reflector at 160 meters. Water depth is 3338 meters. Two major lithic units are present at this site: a pelagic sequence is underlain by volcanicterrigeneous sediments.

Hole 154 was spot cored at 51 to 61 meters (Pleistocene) and 108 to 117 meters (Early Pliocene). Continuous coring began at 164 meters, near the boundary of the two lithologic units, and penetrated the volcanicterrigeneous sediments to 277 meters. These are of Early Pliocene age; the basal part is possibly Late Miocene (Figure 13).

In Cores 1 and 2, planktonic foraminifera are abundant. They are less frequent in the upper part of Core 3 and become generally scarce to absent from the lower part of Core 3 to Core 14 . The sediments, very poor in, or void of foraminifera, consist of volcanic and sedimentary terrestrial material including occasional plant fragments, e.g., in Core 12 (CC).

Hole $154 \mathrm{~A}$ was continuously cored from the top to 172 meters, thus overlapping with the continuously cored section of 154 . Hole $154 \mathrm{~A}$ recovered a section beginning with the Pleistocene Globigerina bermudezi Subzone and continuing to the Globorotalia margaritae margaritae Zone in the Early Pliocene (Figure 14). See also Figure 3.

In Hole 154A, planktonic foraminifera are abundant and generally well-preserved from Core 1 to Core 15; they become increasingly scarce in Core 16 and practically absent in Cores 17 and 18, which consist of volcanic and terrestrial material.

For comparison with the detailed investigations on the Pleistocene-Holocene of Site 147, the percentage of some selected species in relation to the total planktonic foraminiferal fauna and relationship of cold- and warm-water forms was investigated in the Pleistocene of Hole 154A (Figure 15). Reference is made in this connection to Figure 3 of Rögl and Bolli in this Volume, where the climatic results are compared with those of Sites 147 and 148.

\section{Remarks on the Correlation of Hole 154 with Hole 154A}

Correlation of the overlapping parts of Holes 154 and $154 \mathrm{~A}$ based on the planktonic foraminifera distribution has posed some problems.

Hole 154 was drilled continuously from 164 to 277 meters and Hole 154A from sea-bottom to 172 meters. Within these two continuously cored sections, Core 3 of Hole $154(164$ to $173 \mathrm{~m})$ and Core 18 of Hole 154A (163 to $174 \mathrm{~m}$ ) should practically overlap. However, according to shipboard notes on lithology and subsequent faunal examination of samples, the two cores, expected to be identical, in fact, show some marked differences. Core $154 \mathrm{~A}-18$ (the same as the next higher Core 17) consists throughout of volcanic-terrestrial sedimentary material, with virtually no foraminifera.

Core $154-3$ is disturbed and has a comparatively poor recovery. Section 1 was therefore not sampled for these reasons. Two samples taken in the similarly disturbed Section 2 (at 2 to 4 and 94 to $96 \mathrm{~cm}$ ) and a sample from Section 3, at 7 to $9 \mathrm{~cm}$, contain rich planktonic foraminiferal faunas. The interval below $14 \mathrm{~cm}$ of Section 3 (which is the last in Core 3) consists of volcanic material, apparently practically void of foraminifera.

From the upper foraminifer-rich part of 154-3, it would appear that it compares best with Core 15 of $154 \mathrm{~A}$ (134 to $144 \mathrm{~m}$ ). Faunistically, such correlation is supported by the presence in both cores of dextrally coiling Pulleniatina obliquiloculata primitiva, Globigerinoides ruber and Sphaeroidinella dehiscens. The next deeper Core 4 of Hole 154 is practically void of foraminifera but Core 5 again contains a reasonable fauna, this time with sinistrally coiling $P$. obliquiloculata primitiva and no $G$. ruber or $S$. dehiscens. The same faunal change is also observed in Core 16 of Hole $154 \mathrm{~A}$.

A correlation based on the above mentioned foraminiferal faunas of Core 154-3 (upper part) with Core 154A-15, respectively, and of Core 154-5 with Core 154A-16, leads to a discrepancy of some 30 meters or more in depth figures given in the drilling record for these barrels.

These discrepancies appear to be due to either (a) slumping and resulting strong contamination with younger sediments of Cores 3 and 5 of Hole 154, (b) faulty depth figures given for certain cores in Holes 154 and/or $154 \mathrm{~A}$, or (c) a possible change in thickness of the beds over the unknown but certainly short horizontal distance, that separates Holes 154 and 154A. The quite poor recovery in Cores 3 and 5 of Hole 154, and their obviously mixed contents (volcanics and sediments rich in microfaunas), would point to the first mentioned possibility. However, in accepting contamination with younger sediments in Cores 3 and 5 , there remains the somewhat disquieting fact that, based on the distribution of the foraminiferal fauna in these cores, the slumping of the younger material into them would seem to have occurred in normal stratigraphic order.

\section{ACKNOWLEDGMENTS}

The writers wish to thank the Deep Sea Drilling Project for having invited them to participate in the Glomar Challenger Caribbean Leg 15. The Federal Institute of Technology, Zürich, and the University of Milano kindly granted to them the necessary leaves of absences, and their respective Geological Institutes made available laboratory facilities and technical help for the preparation of this report. Monique Toumarkine assisted in assembling the Site 148 information. Fred Rögl has studied the taxonomy, distribution, and ecology of the planktonic foraminifera in Site 147. The results are jointly published elsewhere in this Volume, but many of his findings on Site 147, and the faunal percentage charts on Sites 148 and 154 (154A) which he prepared, are included here. The manuscript, in particular aspects on taxonomy and stratigraphy, were discussed with Jean Pierre Beckmann. 
H. M. BOLLI, I. PREMOLI SILVA

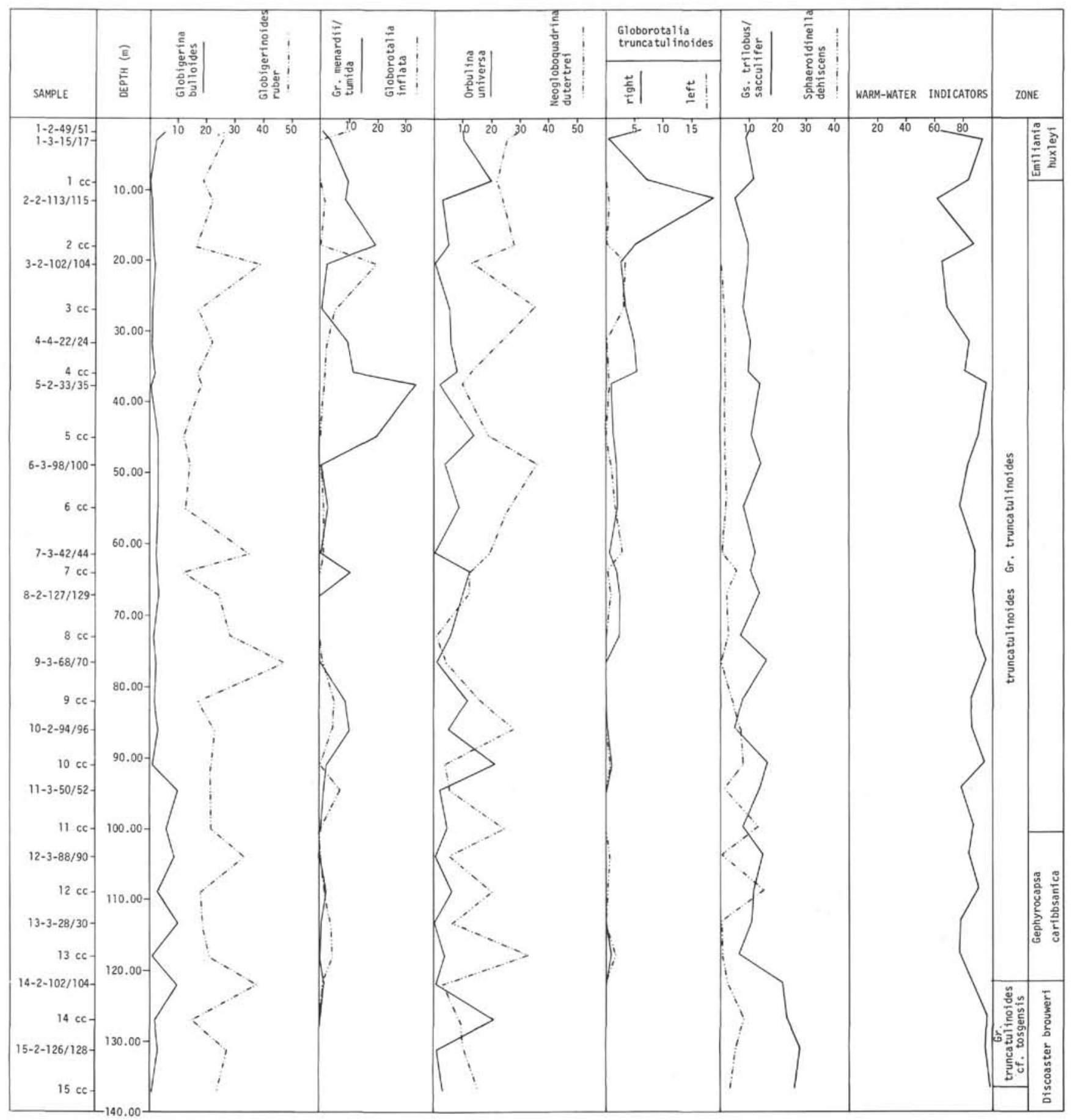

Figure 14. Percentage of some selected species in relation to total planktonic foraminiferal fauna, and relationship of coldand warm-water species (Pleistocene) in Site 148. 


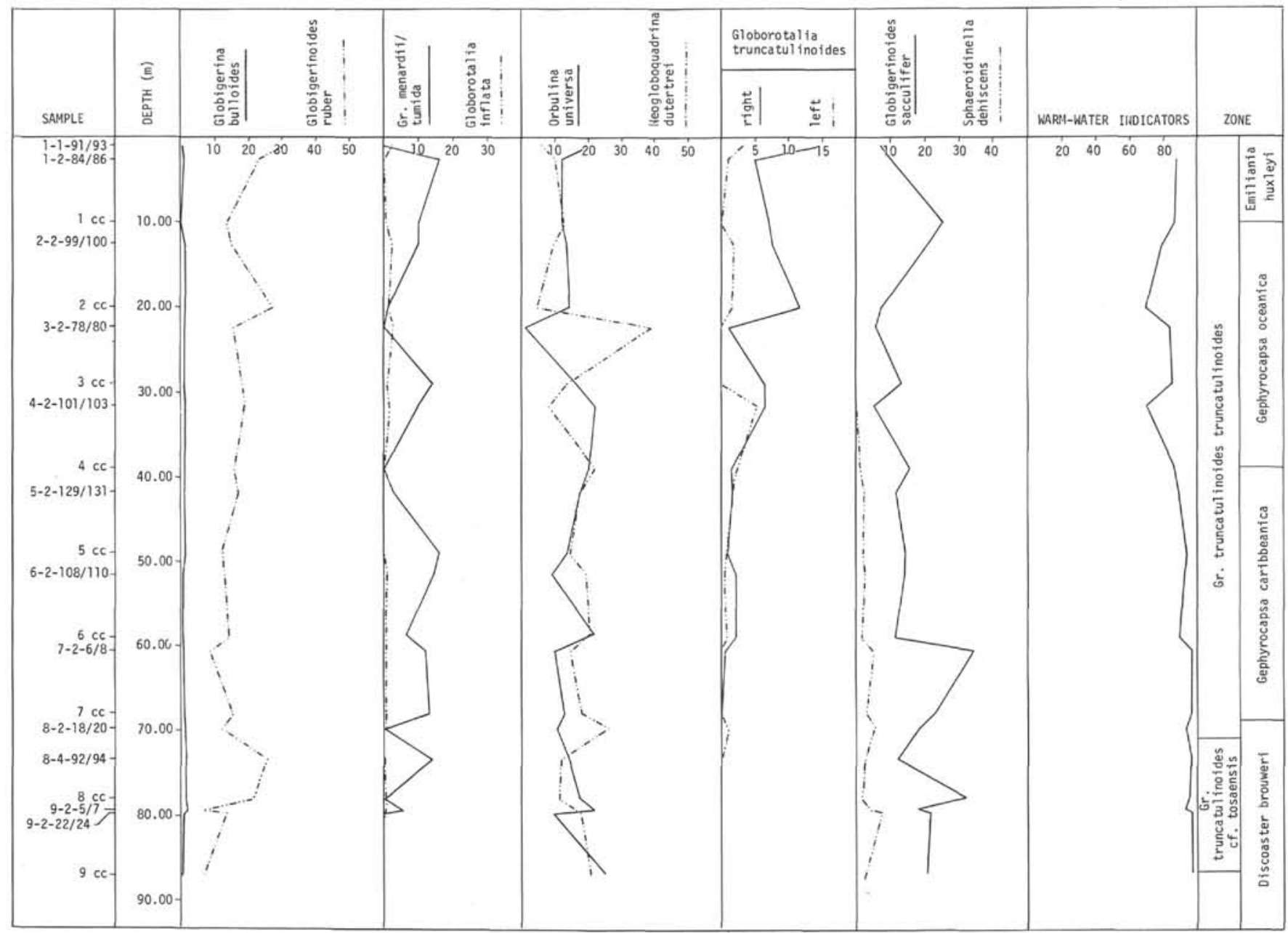

Figure 15. Percentage of some selected species in relation to total planktonic foraminiferal fauna, and relationship of coldand warm-water species (Pleistocene) in Hole 154A.

\section{REFERENCES}

Banner, F. T. and Blow, W. H., 1960. Some primary types of species belonging to the superfamily Globigerinaceae. Cushman Found. Foram Res. 11 (1), 1.

Beckmann, J. P., 1972. The foraminifera and some associated microfossils of Sites 135-144, In Hayes, D.E., Pimm, H. C. et al., 1972. Initial Reports of the Deep Sea Drilling Project, Volume 14, Washington (U.S. Government Printing Office). 389.

Blow, W. H., 1969. Late Middle Eocene to Recent planktonic foraminiferal biostratigraphy. Proc. First. Int. Conf. Plankt. Microfossils, Geneva 1967. 1, 199.

Bolli, H. M. and Bermudez, P. J., 1965. Zonation based on planktonic foraminifera of Middle Miocene to Pliocene warm-water sediments. Assoc. Ven. Geol. Min. Petrol,, Bol. Inf. 8 (5), 119.

Bolli, H. M., 1966a. Zonation of Cretaceous to Pliocene marine sediments based on planktonic foraminifera. Boll. Assoc. Venezolana Geol. Mineria Petrol. 9 (1), 3. 1966b. The planktonic foraminifera in well Bodjonegoro-1 of Java. Eclogae Geol. Helv. 59 (1), 449. 1970. The foraminifera of Sites 23-31, Leg 4. In

Bader, R.G., Gerard, R.D. et al., 1970. Initial Reports of the Deep Sea Drilling Project, Volume 4. Washington (U.S. Government Printing Office), 577.

Cita, M. B., 1973. Pliocene biostratigraphy and chronostratigraphy. In Ryan, W.B.F., Hsw, K.T. et al., 1973.

Emiliani, C., 1966. Paleotemperature analysis of Caribbean cores P 6304-8 and P 6304-9 and a generalized temperature curve for the past 425,000 years. J. Geol. 74 (2), 109.

Emiliani, C., 1969. A new paleontology. Micropaleontology. 15 (3), 265.

Ericson, D. B., Ewing, M., Wollin, G. and Heezen, B.C., 1961. Atlantic deep-sea sediment cores. Bull. Geol. Soc. Am. 72, 193.

Ericson, D. B. and Wollin, G., 1968. Pleistocene climates and chronology in deep-sea sediments. Science. 162, 1227.

Lamb, J. L. and Beard, J. H., 1972. Late Neogene planktonic foraminifera in the Caribbean, Gulf of Mexico, and Italian stratotypes. Univ. Kansas Pal. Contrib., Article 57 (Protozoa 8), 1.

Moore, T. C., Jr., 1972. DSDP: Success, failures, proposals. Geotimes. 17 (7), 27. 